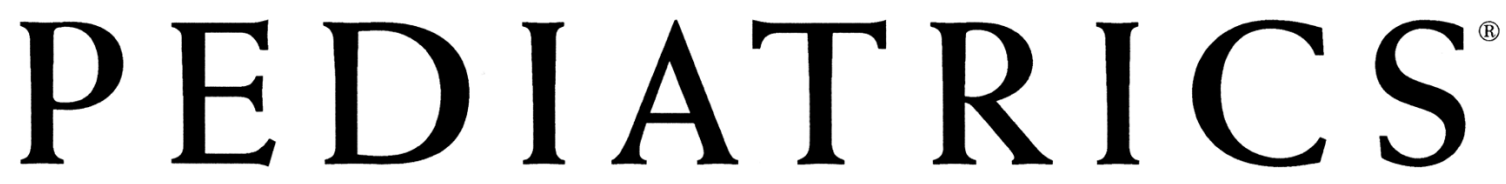

OFFICIAL JOURNAL OF THE AMERICAN ACADEMY OF PEDIATRICS

\title{
Evaluation, Diagnosis, and Treatment of Gastrointestinal Disorders in Individuals With ASDs: A Consensus Report
}

Timothy Buie, Daniel B. Campbell, George J. Fuchs, III, Glenn T. Furuta, Joseph Levy, Judy VandeWater, Agnes H. Whitaker, Dan Atkins, Margaret L. Bauman, Arthur L. Beaudet, Edward G. Carr, Michael D. Gershon, Susan L. Hyman, Pipop Jirapinyo, Harumi Jyonouchi, Koorosh Kooros, Rafail Kushak, Pat Levitt, Susan E. Levy, Jeffery D. Lewis, Katherine F. Murray, Marvin R. Natowicz, Aderbal Sabra, Barry K. Wershil, Sharon C. Weston, Lonnie Zeltzer and Harland Winter Pediatrics 2010;125;S1-S18

DOI: $10.1542 /$ peds.2009-1878C

The online version of this article, along with updated information and services, is located on the World Wide Web at:

http://www.pediatrics.org/cgi/content/full/125/Supplement_1/S1

PEDIATRICS is the official journal of the American Academy of Pediatrics. A monthly publication, it has been published continuously since 1948. PEDIATRICS is owned, published, and trademarked by the American Academy of Pediatrics, 141 Northwest Point Boulevard, Elk Grove Village, Illinois, 60007. Copyright @ 2010 by the American Academy of Pediatrics. All rights reserved. Print ISSN: 0031-4005. Online ISSN: 1098-4275.

\section{American Academy of Pediatrics}

DEDICATED TO THE HEALTH OF ALL CHILDREN ${ }^{m}$ 


\section{Evaluation, Diagnosis, and Treatment of Gastrointestinal Disorders in Individuals With ASDs: A Consensus Report}

AUTHORS: Timothy Buie, MD, a,b,c Daniel B. Campbell, PhD, ${ }^{d}$ George J. Fuchs, III, MD, e Glenn T. Furuta, MD,f,g Joseph Levy, MD, ${ }^{\mathrm{h}}$ Judy Van de Water, PhD, ${ }^{i}$ Agnes $H$. Whitaker, MD,j Dan Atkins, MD, k,l Margaret L. Bauman, MD, b,m,n Arthur L. Beaudet, MD, ${ }^{0}$ Edward G. Carr, PhD, ${ }^{\mathrm{p}}$ Michael D.

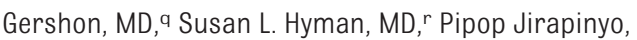

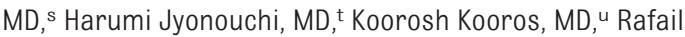
Kushak, PhD, DrSc, ${ }^{\text {a,m }}$ Pat Levitt, PhD, ${ }^{\vee}$ Susan E. Levy, MD, ${ }^{w}$ Jeffery D. Lewis, MD, ${ }^{\mathrm{x}}$ Katherine F. Murray, BSN, RN, ${ }^{\mathrm{C}}$ Marvin R. Natowicz, MD, PhD, ${ }^{y}$ Aderbal Sabra, MD, PhD, ${ }^{2}$ Barry K. Wershil, MD, ${ }^{\text {aa }}$ Sharon C. Weston, MS, RD, LDN, ${ }^{\text {bb }}$ Lonnie Zeltzer, MD, ${ }^{\mathrm{cc}}$ and Harland Winter, MDa,c

aDepartment of Pediatrics, Harvard Medical School, Boston, Massachusetts; ${ }^{b}$ Learning and Development Disabilities Evaluation and Rehabilitation Services, Lexington, Massachusetts; ' Division of Pediatric Gastroenterology and Nutrition; ${ }^{m}$ Department of Pediatrics, and ${ }^{n}$ Department of Neurology, MassGeneral Hospital for Children, Boston,

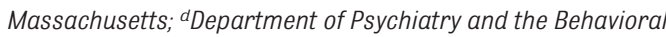
Sciences, Keck School of Medicine of University of Southern California, Los Angeles, California; 'Division of Pediatric Gastroenterology, Hepatology, and Nutrition, University of Arkansas for Medical Sciences, Arkansas Children's Hospital, Little Rock, Arkansas; 'S Section of Pediatric Gastroenterology, Hepatology and Nutrition, Children's Hospital Denver, Aurora, Colorado, and Department of Pediatrics, National Jewish Health Denver, Colorado; ${ }^{g}$ Department of Pediatrics, University of Colorado Denver School of Medicine, Aurora, Colorado; ${ }^{h}$ Department of Pediatrics (Administration), NYU Langone LangoneMedical Center, New York University School of Medicine New York, New York; 'Division of Rheumatology, Allergy and Clinical Immunology, Department of Internal Medicine, University of California, Davis, California; 'Department of Psychiatry, Division of Child and Adolescent Psychiatry, New York-Presbyterian Hospital, Columbia University Medical Center, New York, New York; ${ }^{k}$ Division of Ambulatory Pediatrics, Department of Pediatrics, National Jewish Health, Children's Hospital, Denver, Colorado; 'Department of Pediatrics, University of Colorado Denver School of Medicine, Denver, Colorado; -Department of Molecular and Human Genetics, Baylor College of Medicine, Houston, Texas; ${ }^{p}$ Department of Psychology, State University of New York, Stony Brook, New York; ${ }^{a}$ Department of Pathology \& Cell Biology, Columbia University College of Physicians and Surgeons, New York, New York; 'Division of Neurodevelopmental and Behavioral Pediatrics, Golisano Children's Hospital at Strong, University of Rochester Medical Center, Rochester, New York; 's Department of Pediatrics, Siriraj Hospital, Mahidol University, Bangkok, Thailand; ${ }^{t}$ Division of Allergy/Immunology and Infectious Diseases, Pediatrics, New Jersey Medical School, University of Medicine and Dentistry of New Jersey, Newark, New Jersey; " Division of Pediatric Gastroenterology and Nutrition, Golisano Children's Hospital at Strong, University of Rochester Medical Center, Rochester, New York; vZilkha Neurogenetic Institute \& Dept. Cell and Neurobiology (Dr Levitt), Keck School of Medicine of University

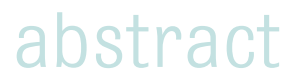

Autism spectrum disorders (ASDs) are common and clinically heterogeneous neurodevelopmental disorders. Gastrointestinal disorders and associated symptoms are commonly reported in individuals with ASDs, but key issues such as the prevalence and best treatment of these conditions are incompletely understood. A central difficulty in recognizing and characterizing gastrointestinal dysfunction with ASDs is the communication difficulties experienced by many affected individuals. A multidisciplinary panel reviewed the medical literature with the aim of generating evidence-based recommendations for diagnostic evaluation and management of gastrointestinal problems in this patient population. The panel concluded that evidence-based recommendations are not yet available. The consensus expert opinion of the panel was that individuals with ASDs deserve the same thoroughness and standard of care in the diagnostic workup and treatment of gastrointestinal concerns as should occur for patients without ASDs. Care providers should be aware that problem behavior in patients with ASDs may be the primary or sole symptom of the underlying medical condition, including some gastrointestinal disorders. For these patients, integration of behavioral and medical care may be most beneficial. Priorities for future research are identified to advance our understanding and management of gastrointestinal disorders in persons with ASDs. Pediatrics 2010;125:S1-S18 
Autism spectrum disorders (ASDs) are a group of developmental disorders characterized by impairments in social interaction; varying degrees of verbal and nonverbal communication deficits; and restricted, repetitive, and stereotyped patterns of behavior and interests. The term includes autistic disorder, Asperger disorder, and pervasive developmental disorder, not otherwise specified (PDD-NOS). ${ }^{1}$ Approximately 1 of every 150 children in the United States has an ASD. ${ }^{2}$ In these children, a variety of gastrointestinal dysfunctions and associated symptoms have been reported frequently.

Gastrointestinal problems in individuals with ASDs can be challenging to evaluate. Clinical practice guidelines exist for the evaluation and management of ASDs by primary care and other physicians responsible for the care of individuals with ASDs but do not include routine consideration of potential gastrointestinal and other medical problems. ${ }^{1,3-5}$ Many individuals with ASDs are nonverbal or minimally verbal and cannot express pain or discomfort through speech. As a result, they may not communicate information about their symptoms as clearly as their typically developing peers. Even individuals with ASDs who acquire verbal communication skills may have difficulty describing subjective experiences or symptoms.

On May 29-30, 2008, a multidisciplinary panel convened in Boston, Massachusetts, to review and discuss gastrointestinal aspects of ASDs. Meeting participants were part of a larger group that was organized to develop recommendations for the evaluation and management of gastrointestinal disorders for individuals with ASDs, as well as for future research directions. Working groups comprised 28 experts in child psychiatry, developmental pediatrics, epidemiology, medical genetics, immunology, nurs- ing, pediatric allergy, pediatric gastroenterology, pediatric pain, pediatric neurology, pediatric nutrition, and psychology. ${ }^{*}$ All of these experts are experienced in providing clinical care or addressing research questions related to individuals with ASDs and reviewed the published literature before the meeting.

\section{METHODS}

A literature search on Medline was conducted to identify relevant articles by using the key words "gastrointestinal disease" and "autism." Results of the search were complemented by additional publications identified by participants. Each article was assigned to 2 working group members (one as a primary reader and the other as a secondary reader) who reviewed the articles and assigned a score based on a modified Grading of Recommendations Assessment, Development, and Evaluation (GRADE) system of evaluation. ${ }^{6,7}$ With this modified system, one assigns 2 scores that rate the type and quality of evidence according to specific criteria (Table 1).8 Committee members were encouraged to review but not necessarily grade all articles. In advance of the panel meeting, each committee met via conference call to discuss and arrive at a consensus evaluation of each article.

At the Boston meeting, the chairs of 7 working groups summarized their findings and suggested statements on the prevalence of gastrointestinal and

\footnotetext{
*The 7 working groups were the Allergy Working Group (Drs Furuta [chair], Atkins, Jyonouchi, and SE Levy), Gl Symptoms Working Group (Drs Fuchs [chair], Gershon, Kooros, and Winter), Genetics Working Group (Drs Campbell [chair], Beaudet, Natowicz, and Levitt), Immunology/Inflammation Working Group (Drs Van de Water [chair], Wershil, and Sabra), Interpretation of Abdominal Pain Working Group (Drs Whitaker [chair], Bauman, Buie, and Carr, Ms Murray, and Dr Zeltzer), Metabolism and Maldigestion Working Group (Drs J Levy [chair], Kushak, and Lewis), and Nutrition Working Group (Drs Buie [chair], Hyman, and Jirapinyo, Ms Weston, and Dr Winter).
}

associated conditions, as well as potential etiology, diagnosis, treatment, and future research. Potential associated conditions included food allergies and other adverse reactions to foods, immunologic dysfunction, inflammation, metabolic dysfunction, and nutritional deficiencies.

The nominal group technique was used to review and refine these statements, with consensus reached by 1 or more rounds of voting. Voting members used electronic key pads to select a number between 1 and 9 ; a vote of 1 signified complete disagreement with a statement, whereas a vote of 9 signified complete agreement. To achieve consensus, all voting members had to score a statement with either 1 to 3 (signifying consensus on disagreement) or 7 to 9 (signifying consensus on agreement). If consensus were not achieved, the statement was modified and another vote was taken. The process was repeated until consensus was achieved or a decision was made by the group that it was not possible to achieve agreement. A total of 10 to 13 participants in attendance voted on 23 statements. $\dagger$

The consensus statements and discussion highlights were summarized as draft proceedings of the meeting, which then were edited and expanded on by all members of each working group. The participants have contributed equally to the final consensus report.

\section{CONSENSUS STATEMENTS}

Because of the absence, in general, of high-quality clinical research data, evidence-based recommendations are not possible at the present time. However, the panel agreed on a number of

†A total of 14 participants attended the May 2008 meeting in Boston as voting members: the working group chairs (Drs Buie, Campbell, Fuchs, Furuta, Levy, Van de Water, and Whitaker), Drs Atkins, Bauman, Jirapinyo, and Kushak, Ms Murray, and Drs Sabra and Winter 
TABLE 1 GRADE System Definitions

\begin{tabular}{cr}
\hline \multicolumn{1}{c}{ Type of Evidence } & Quality of Evidence \\
\hline High: evidence based on randomized, & High quality: additional research is very unlikely to \\
controlled trials & change our confidence in the estimate of effect. \\
Low: evidence based on & Moderate quality: additional research is likely to have an \\
observational studies & important impact on our confidence in the estimate of \\
Very low: any other evidence & effect and may change the estimate. \\
& Low quality: additional research is very likely to have an \\
& important impact on our confidence in the estimate of \\
effect and is likely to change the estimate. & Very low quality: Any estimate of effect is very uncertain.
\end{tabular}

Critiques (review articles and editorials) are ineligible for assessment by the GRADE system of evaluation.

Adapted with permission from BMJ Publishing Group Ltd from Atkins D, Best D, Briss PA, et al; GRADE Working Group. BMJ. 2004;328(7454):1490.

statements based on expert opinion that arose from a review of existing evidence. It is acknowledged that, in many areas, evidence is generally confined to case reports, observational or descriptive studies, and poorly controlled or uncontrolled studies.

The expert panel reached consensus on the following statements.

\section{Statement 1 (Key Statement)}

Individuals with ASDs who present with gastrointestinal symptoms warrant a thorough evaluation, as would be undertaken for individuals without ASDs who have the same symptoms or signs. Evidence-based algorithms for the assessment of abdominal pain, constipation, chronic diarrhea, and gastroesophageal reflux disease (GERD) should be developed.

Individuals with ASDs deserve the same thorough diagnostic workup for gastrointestinal symptoms as should occur for other patients. There is no evidence for pathogenic mechanisms specific to ASDs that warrant a distinct diagnostic approach. Guidelines for the evaluation of common gastrointestinal symptoms have been developed by medical societies, medical centers, and managed care practices. ${ }^{9-12} \mathrm{Few}$, if any, published documents have addressed modifications in the diagnostic evaluation on the basis of the needs of persons with disabilities such as impaired language. An evidence base is needed to guide evaluation and therapy, but until appropriate studies are conducted, guidelines must be based on expert opinion.

\section{Statement 2}

Gastrointestinal conditions that are reported to be common in individuals without ASDs are also encountered in individuals with ASDs.

In persons with ASDs, gastrointestinal conditions can present typically or atypically as nongastrointestinal manifestations, including behavioral change and/or problem behaviors. Symptom severity can be quite variable in patients with ASDs, as in other patients.

The most common gastrointestinal symptoms and signs reported for persons with ASDs are chronic constipation, abdominal pain with or without diarrhea, and encopresis as a consequence of constipation. Other gastrointestinal abnormalities that have been described for individuals with ASDs include GERD, abdominal bloating, and disaccharidase deficiencies, as well as pathologic findings such as inflammation of the gastrointestinal tract and abnormalities of the enteric nervous system.

Gastrointestinal disorders can present as nongastrointestinal problems. For example, Horvath and Perman ${ }^{13}$ reported disturbed sleep and nighttime awakening for $52 \%$ of children with ASDs who had gastrointestinal symptoms (vs $7 \%$ of age-matched healthy siblings; $P<.001)$. Children with ASDs who had reflux esophagitis exhibited unexplained irritability more frequently $(43 \%)$ than those who did not (13\%). ${ }^{13}$ Behaviors, including problem behavior, may be markers of abdominal pain or discomfort in individuals with ASDs. ${ }^{14,15}$ Table 2 identifies some vocal and motor behaviors, as well as changes in overall state, that may indicate abdominal pain or discomfort.

The diagnostic evaluation of potential gastrointestinal disorders can vary depending on the possible problem (Table 3). For example, if one suspects that maldigestion or malabsorption is causing abdominal distension or is associated with self-injurious behavior, an upper endoscopy with measurement of disaccharidases might be considered. Lactose intolerance is common in the general population and therefore common in individuals with ASDs. To clarify the diagnosis, empiric trials of lactase supplementation or dietary restriction might be considered, in the proper clinical context, before referral to a gastrointestinal specialist.

As for individuals without ASDs, functional abdominal pain (FAP) and irritable bowel syndrome (IBS) can present in individuals with ASDs with behavioral indicators of pain, disordered sleep, diarrhea and/or constipation, and bloating and/or flatulence. The diagnosis of FAP or IBS is a clinical one that is made on the basis of a pattern of predominant symptoms occurring over time in the absence of organic disease. Empiric treatment, initiated by a gastroenterologist or specialist skilled in understanding neurenteric dysregulation, may be warranted for some patients without other indicators of disease, such as weight loss, fever, and bloody stools, before proceeding to invasive evaluations. How- 
TABLE 2 Behaviors That May Be Markers of Abdominal Pain or Discomfort in Individuals With ASDs

\begin{tabular}{|c|c|c|}
\hline Vocal Behaviors & Motor Behaviors ${ }^{a}$ & Changes in Overall State \\
\hline $\begin{array}{l}\text { Frequent clearing of throat, swallowing, } \\
\text { tics, etc }\end{array}$ & Facial grimacing & $\begin{array}{l}\text { Sleep disturbances: difficulty getting to sleep, } \\
\text { difficulty staying asleep }\end{array}$ \\
\hline Screaming & Gritting teeth & $\begin{array}{l}\text { Increased irritability (exaggerated responses to } \\
\text { stimulation) }\end{array}$ \\
\hline Sobbing "for no reason at all" & Wincing & Noncompliance with demands that typically elicit an \\
\hline Sighing, whining & Constant eating/drinking/swallowing ("grazing” behavior) & appropriate response (oppositional behavior) \\
\hline Moaning, groaning & $\begin{array}{l}\text { Mouthing behaviors: chewing on clothes (shirt sleeve cuff, } \\
\text { neck of shirt, etc), pica }\end{array}$ & \\
\hline $\begin{array}{l}\text { Delayed echolalia that includes reference to } \\
\text { pain or stomach (eg, child says, "Does } \\
\text { your tummy hurt?" echoing what mother } \\
\text { may have said to child in the past) }\end{array}$ & $\begin{array}{l}\text { Application of pressure to abdomen: leaning abdomen } \\
\text { against or over furniture or kitchen sink, pressing } \\
\text { hands into abdomen, rubbing abdomen }\end{array}$ & \\
\hline $\begin{array}{l}\text { Direct verbalizations (eg, child says "tummy } \\
\text { hurts" or says "ouch," "ow," "hurts," or } \\
\text { "bad" while pointing to abdomen) }\end{array}$ & $\begin{array}{l}\text { Tapping behavior: finger tapping on throat } \\
\text { Any unusual posturing, which may appear as individual } \\
\text { postures or in various combinations: jaw thrust, neck } \\
\text { torsion, arching of back, odd arm positioning, } \\
\text { rotational distortions of torso/trunk, sensitivity to } \\
\text { being touched in abdominal area/flinching } \\
\text { Agitation: pacing, jumping up and down } \\
\text { Unexplained increase in repetitive behaviors } \\
\text { Self-injurious behaviors: biting, hits/slaps face, head- } \\
\text { banging, unexplained increase in self-injury } \\
\text { Aggression: onset of, or increase in, aggressive behavior }\end{array}$ & \\
\hline
\end{tabular}

A functional behavioral assessment would be useful in interpreting these behaviors.

${ }^{a}$ Motor behaviors also may be markers of pain or discomfort arising in other parts of the body.

ever, for children with ASDs, behavioral indicators may be the only manifestation of pain, and determining who should be evaluated medically and who should be treated empirically can be problematic. Evaluating all children may result in some with IBS and FAP having potentially unnecessary invasive evaluations; treating children empirically may delay identification of morbidities that could be remedied by medical or surgical intervention. Clearly better biomarkers of disease in children with ASDs are needed to reliably identify those individuals who are most likely to benefit from the more comprehensive diagnostic evaluation.

\section{Statement 3}

The prevalence of gastrointestinal $a b$ normalities in individuals with ASDs is incompletely understood.

The reported prevalence of gastrointestinal symptoms in children with ASDs has ranged from $9 \%$ to $70 \%$ or higher (Table 4). 13,16-25 Prospective descriptive reports from autism clinics have described significant gastrointestinal symptoms in at least $70 \%$ of patients, ${ }^{22}$ data that might reflect a referral bias. In contrast, secondary analysis of a UK database indicated that the prevalence of gastrointestinal symptoms was no different in children with ASDs compared with children without ASDs (9\%) at the time of their initial ASD diagnosis. ${ }^{16}$

Most of these studies had 1 or more methodologic limitations, in particular a lack of appropriate (nonrelated) control groups. Despite the limitations in type and quality of available evidence, the preponderance of data were consistent with the likelihood of a high prevalence of gastrointestinal symptoms and disorders associated with ASDs.

The panel agreed that to unequivocally answer the important question of prevalence of gastrointestinal dys- function in this population, prospective multicenter studies need to be performed by using validated instruments and outcome measures administered to persons with a diagnosis of ASD established by accepted methods and appropriate control groups. Population-based studies are also needed to avoid referral bias and overestimation of the prevalence of gastrointestinal symptoms in patients with ASDs.

\section{Statement 4}

The existence of a gastrointestinal disturbance specific to persons with ASDs (eg, "autistic enterocolitis") has not been established.

Some health care providers and researchers have proposed that certain gastrointestinal pathologies are specific to individuals with ASDs. An immune or inflammation-mediated mechanism specific to ASDs, possibly vaccinetriggered in the setting of abnormal immune function or increased gut per- 
TABLE 3 Diagnostic Evaluation of Gastrointestinal Symptoms and Disorders in Individuals With ASDs

\begin{tabular}{|c|c|c|c|}
\hline Symptom & $\begin{array}{l}\text { Possible Associated } \\
\text { Gastrointestinal Disorder }\end{array}$ & Definition & Diagnostic Evaluations to Be Considered \\
\hline Sleep disturbance & GERD & Parental/provider report & $\begin{array}{l}\text { (1) Diagnostic trial of proton-pump inhibitor; } \\
\text { (2) } \mathrm{pH} \text { probe, EGD }\end{array}$ \\
\hline $\begin{array}{l}\text { Self-injurious behavior, tantrums, } \\
\text { aggression, oppositional } \\
\text { behavior }\end{array}$ & $\begin{array}{l}\text { Constipation, GERD, gastritis, } \\
\text { intestinal inflammation }\end{array}$ & Parental/provider report & $\begin{array}{l}\text { (1) Abdominal radiograph; (2) diagnostic } \\
\text { trial of proton-pump inhibitor or PEG } \\
\text { 3350; (3) pH probe, EGD, colonoscopy }\end{array}$ \\
\hline Chronic diarrhea & Malabsorption, maldigestion & $\geq 3$ loose stools daily for $>2 \mathrm{wk}$ & $\begin{array}{l}\text { (1) Stool analysis for occult blood, enteric } \\
\text { pathogens, ova/parasites (Giardia or } \\
\text { Cryptosporidium), Clostridium difficile; (2) } \\
\text { consider PEG } 3350 \text { if overflow diarrhea is } \\
\text { a possibility; (3) lactose breath test (or } \\
\text { measure lactase-specific activity), EGD, } \\
\text { colonoscopy }\end{array}$ \\
\hline $\begin{array}{l}\text { Straining to pass stool, hard or } \\
\text { infrequent stool }\end{array}$ & Constipation & $\begin{array}{l}\leq 2 \text { hard stools per week (Bristol } \\
\text { stool score) }\end{array}$ & $\begin{array}{l}\text { (1) Abdominal radiograph to look for fecal } \\
\text { impaction; (2) diagnostic trial of PEG } 3350\end{array}$ \\
\hline $\begin{array}{l}\text { Perceived abdominal discomfort: } \\
\text { pressing abdomen, holding } \\
\text { abdomen and crying, problem } \\
\text { behaviors related to meals }\end{array}$ & $\begin{array}{l}\text { Constipation, GERD, } \\
\text { intestinal inflammation, } \\
\text { malabsorption, } \\
\text { maldigestion }\end{array}$ & & $\begin{array}{l}\text { (1) Diagnostic trial of proton-pump inhibitor } \\
\text { or PEG 3350; (2) abdominal radiograph; } \\
\text { (3) lactose breath test (or measure } \\
\text { lactase-specific activity); (4) pH probe, } \\
\text { EGD, colonoscopy }\end{array}$ \\
\hline Flatulence and/or bloating & $\begin{array}{l}\text { Constipation, lactose } \\
\text { intolerance, enteric } \\
\text { infection with Giardia or } \\
\text { Cryptosporidium }\end{array}$ & & $\begin{array}{l}\text { (1) Abdominal radiograph; (2) diagnostic } \\
\text { trial of PEG } 3350 \text { or lactose restriction; (3) } \\
\text { lactose breath test or EGD (measure } \\
\text { lactase-specific activity) }\end{array}$ \\
\hline Any or all of the above & FAP, IBS & $\begin{array}{l}\text { FAP: abdominal pain without } \\
\text { demonstrable evidence of } \\
\text { anatomic, metabolic, } \\
\text { infectious, inflammatory, } \\
\text { neoplastic, or other pathologic } \\
\text { condition } \\
\text { IBS: FAP associated with } \\
\text { alteration in bowel } \\
\text { movements }\end{array}$ & $\begin{array}{l}\text { (1) Behavioral soothing; (2) diet } \\
\text { enhancements with fruits, fiber, sufficient } \\
\text { fluids; (3) increase in routines for sleep } \\
\text { and toilet time }\end{array}$ \\
\hline
\end{tabular}

EGD indicates esophagogastroduodenoscopy; PEG, polyethylene glycol.

meability ("leaky gut”), has been hypothesized to underlie the gastrointestinal disorders seen in individuals with ASDs, mainly on the basis of a finding of ileal nodular lymphoid hyperplasia $(\mathrm{NLH})$ and/or chronic colitis seen on colonoscopy.

In 1998, Wakefield et al ${ }^{26}$ reported an association between ileocolitis and developmental regression in 12 children and coined the term "autistic enterocolitis." From the same uncontrolled study they reported NLH of the ileum and colon as an abnormal finding in most children with ASDs. However, similar findings are known to be present in children with typical development, as well as children with food allergies and immunodeficiencies. ${ }^{27,28}$ The significance of these findings, therefore, is unclear. Wakefield et al ${ }^{29}$ also proposed a causal relation between measles, mumps, and rubella (MMR) vaccination and autism, a suggestion that was later retracted by many of the original authors.

Other study-design limitations in these reports included flawed control groups, lack of validated and standardized definitions, and speculative interpretation of results. In summary, published reports have not established the presence of a unique gastrointestinal pathophysiology specific to ASDs.

\section{Statement 5}

The evidence for abnormal gastrointestinal permeability in individuals with ASDs is limited. Prospective stud- ies should be performed to determine the role of abnormal permeability in neuropsychiatric manifestations of ASDs.

Altered intestinal permeability was reported in 9 of 21 (43\%) children with ASDs and 0 of 40 healthy age-matched controls. ${ }^{30}$ The authors of the study speculated that the alteration might be the mechanism for increased passage of food-derived peptides through a damaged gut mucosa. Increased permeability (or a "leaky gut") has been cited as having a key role in various hypotheses regarding the biology of ASDs, including excess opiate activity, diminished peptidase activity, and immune dysfunction. ${ }^{31}$ Some investigators have reported decreased serum sulfate levels in children with ASDs and 
TABLE 4 Prevalence of Gastrointestinal Symptoms in Individuals With ASDs

\begin{tabular}{|c|c|c|c|c|c|c|}
\hline Source & Overall Prevalence & $\begin{array}{c}\text { Prevalence of Specific } \\
\text { Disorders }\end{array}$ & $\begin{array}{c}\text { Sample } \\
\text { Size }\end{array}$ & $\begin{array}{c}\text { Sample } \\
\text { Characteristics }\end{array}$ & Control & Comments \\
\hline Black et al ${ }^{16}(2002)$ & $\begin{array}{l}\text { 9\% with } \\
\quad \text { gastrointestinal } \\
\text { disease (vs 9\%)a }\end{array}$ & - & 96 & $\begin{array}{l}\text { Children with later } \\
\text { diagnosis of ASD }\end{array}$ & $\begin{array}{l}449 \text { children matched } \\
\text { for age, gender, } \\
\text { practice, and index } \\
\text { date (date of first } \\
\text { recorded diagnosis } \\
\text { of ASD) }\end{array}$ & $\begin{array}{l}\text { Nested case-control } \\
\text { study; UK General } \\
\text { Practice Database } \\
\text { ( } N=211480 ; \\
\text { general practitioner } \\
\text { records of recurrent } \\
\text { gastrointestinal } \\
\text { symptoms) }\end{array}$ \\
\hline Taylor et al' ${ }^{17}$ (2002) & $\begin{array}{l}17 \% \text { with chronic } \\
\text { bowel symptoms } \\
\quad \text { (lasting } \geq 3 \mathrm{mo} \text { ) }\end{array}$ & $\begin{array}{l}\text { 8.9\% chronic } \\
\text { constipation; } 4.0 \% \\
\text { diarrhea; } 1.5 \% \\
\text { constipation and } \\
\text { diarrhea }\end{array}$ & 473 & $\begin{array}{l}278 \text { children with } \\
\text { childhood ASDs plus } \\
195 \text { with atypical } \\
\text { ASDs }\end{array}$ & - & $\begin{array}{l}\text { Electronic disability } \\
\text { registries in } 5 \\
\text { London health } \\
\text { districts and special } \\
\text { school and child } \\
\text { psychiatry records; } \\
\text { clinical notes } \\
\text { supplemented by } \\
\text { family } \\
\text { questionnaires }\end{array}$ \\
\hline $\begin{array}{l}\text { Fombonne and } \\
\text { Chakrabarti' }{ }^{18} \text { (2001) }\end{array}$ & $\begin{array}{l}18.8 \% \text { with } \\
\text { gastrointestinal } \\
\text { symptoms }\end{array}$ & $\begin{array}{l}9.4 \% \text { constipation; } \\
5.2 \% \text { abdominal } \\
\text { pain; } 5.2 \% \text { bloody } \\
\text { stools; } 3.1 \% \\
\text { diarrhea }\end{array}$ & 96 & $\begin{array}{l}\text { Post-MMR sample of } \\
\text { children referred } \\
\text { for developmental } \\
\text { problem to local } \\
\text { child development } \\
\text { center who received } \\
\text { PDD diagnosis (26 } \\
\text { with ASDs, } 56 \text { with } \\
\text { atypical ASDs, } 1 \\
\text { with Asperger } \\
\text { syndrome) }\end{array}$ & - & $\begin{array}{l}\text { Part of UK } \\
\text { epidemiologic survey } \\
\text { of PDD; } \\
\text { gastrointestinal } \\
\text { symptom occurrence } \\
\text { assessed by } \\
\text { community } \\
\text { pediatrician alone or } \\
\text { with parent } \\
\text { questionnaire }\end{array}$ \\
\hline Nikolov et al ${ }^{19}$ (2009) & $\begin{array}{l}23 \% \text { with moderate } \\
\text { or severe } \\
\text { gastrointestinal } \\
\text { problems, } \\
\text { primarily } \\
\text { constipation and } \\
\text { diarrhea }\end{array}$ & $\begin{array}{l}2 \% \text { with }>1 \\
\quad \text { moderate }^{\mathrm{b}} \text { or } \\
\text { severe }^{\mathrm{c}} \\
\text { gastrointestinal } \\
\text { problem }\end{array}$ & 172 & $\begin{array}{l}\text { Children with PDDs } \\
\text { (88\% with diagnosis } \\
\text { of ASDs, } 8 \% \text { with } \\
\text { PDD-NOS, } 4 \% \text { with } \\
\text { Asperger } \\
\text { syndrome); } 145 \\
\text { boys, } 27 \text { girls; mean } \\
\text { age: } 8.3 \pm 2.6 \mathrm{y} \\
\text { (range: } 5-17 \text { y) }\end{array}$ & - & $\begin{array}{l}\text { Children enrolled in } 1 \\
\text { of } 2 \text { multisite } \\
\text { randomized clinical } \\
\text { trials conducted by } \\
\text { the RUPP Autism } \\
\text { Network; presence of } \\
\text { gastrointestinal } \\
\text { disorder determined } \\
\text { by medical history } \\
\text { and/or interview } \\
\text { with primary } \\
\text { caretaker using } \\
\text { screening } \\
\text { questionnaire }\end{array}$ \\
\hline $\begin{array}{l}\text { Molloy and Manning- } \\
\text { Courtney }{ }^{20} \text { (2003) }\end{array}$ & $\begin{array}{l}24 \% \text { with } \geq 1 \\
\quad \text { chronic } \\
\text { gastrointestinal } \\
\text { symptom }\end{array}$ & $\begin{array}{l}\text { 12\% chronic diarrhea; } \\
\quad 9 \% \text { chronic } \\
\text { constipation; } 7 \% \\
\text { chronic } \\
\text { reflux/vomiting; } 2 \% \\
\text { abdominal pain; } 2 \% \\
\text { gaseousness }\end{array}$ & 137 & $\begin{array}{l}\text { General population of } \\
\text { children with ASDs } \\
\text { attending autism } \\
\text { clinic and not } \\
\text { referred to } \\
\text { gastroenterologist } \\
\text { for assessment of } \\
\text { gastrointestinal } \\
\text { symptoms }\end{array}$ & - & Single-site study \\
\hline Ming et $\mathrm{al}^{21}$ (2008) & $\begin{array}{l}59 \% \text { with } \\
\text { gastrointestinal } \\
\text { dysfunction }^{\mathrm{b}}\end{array}$ & $\begin{array}{l}\text { Of the } 94(59 \%) \text { with } \\
\text { gastrointestinal } \\
\text { dysfunction: } 38 \% \\
\text { diarrhea or } \\
\text { unformed stools; } \\
28 \% \text { constipation; } \\
19 \% \text { GER }\end{array}$ & 160 & $\begin{array}{l}\text { Children with ASDs } \\
\text { referred to and } \\
\text { consecutively } \\
\text { evaluated at autism } \\
\text { center; all had } \\
\text { validated complete } \\
\text { history (medical } \\
\text { and psychiatric } \\
\text { disorder records) }\end{array}$ & - & $\begin{array}{l}\text { Prevalence based on } \\
\text { retrospective chart } \\
\text { review and clinical } \\
\text { intake forms } \\
\text { completed by } \\
\text { caregivers }\end{array}$ \\
\hline
\end{tabular}


TABLE 4 Continued

\begin{tabular}{|c|c|c|c|c|c|c|}
\hline Source & Overall Prevalence & $\begin{array}{c}\text { Prevalence of Specific } \\
\text { Disorders }\end{array}$ & $\begin{array}{l}\text { Sample } \\
\text { Size }\end{array}$ & $\begin{array}{c}\text { Sample } \\
\text { Characteristics }\end{array}$ & Control & Comments \\
\hline $\begin{array}{l}\text { Valicenti-McDermott } \\
\text { et al22 (2006) }\end{array}$ & $\begin{array}{l}70 \% \text { with } \geq 1 \\
\text { lifetime } \\
\text { gastrointestinal } \\
\text { symptom (vs } 28 \% \\
\text { in typically } \\
\text { developing } \\
\text { subjects [ } P< \\
.001] \text { and } 42 \% \text { in } \\
\text { subjects with } \\
\text { other } \\
\text { developmental } \\
\text { disorders [ } P= \\
.03] \text { ) }\end{array}$ & $\begin{array}{l}44 \% \text { chronic } \\
\text { constipation (vs } 16 \% \\
{[P=.023] \text { and }} \\
38 \%) ; 28 \% \text { fecal } \\
\text { encopresis (vs } 2 \% \\
{[P=.00] \text { and } 12 \%} \\
[P=.012]) ; 18 \% \\
\text { frequent vomiting } \\
\text { (vs } 0 \%[P=.008 \\
\text { and } 8 \% \text { ); } 18 \% \\
\text { abnormal stool } \\
\text { pattern (vs } 4 \% \\
{[P=.039] \text { and } 2 \%} \\
{[P=.021] \text { ) }}\end{array}$ & 50 & $\begin{array}{l}\text { Children with ASDs } \\
\text { aged 1-18 y } \\
\text { followed in } \\
\text { pediatric neurology } \\
\text { and developmental } \\
\text { pediatrics } \\
\text { programs, private } \\
\text { practices, or clinics } \\
\text { at } 2 \text { urban centers }\end{array}$ & $\begin{array}{l}2 \text { control groups } \\
\text { matched for age, } \\
\text { gender, and ethnicity: } \\
50 \text { children with } \\
\text { typical development } \\
\text { and } 50 \text { with other } \\
\text { developmental } \\
\text { disorders }\end{array}$ & $\begin{array}{l}\text { Cross-sectional study in } \\
\text { which lifetime } \\
\text { prevalence rates } \\
\text { were determined by } \\
\text { structured } \\
\text { interviews }\end{array}$ \\
\hline $\begin{array}{l}\text { Horvath and Perman }{ }^{13} \\
\text { (2002) }\end{array}$ & $\begin{array}{l}84.1 \% \text { had } \geq 1 \\
\text { gastrointestinal } \\
\text { symptom (vs } \\
31.2 \%[P< \\
.0001]) ; 41.1 \% \\
\text { had } \geq 4 \\
\text { gastrointestinal } \\
\text { symptoms (vs } \\
5 \% \text { ) }\end{array}$ & $\begin{array}{l}44 \% \text { abdominal } \\
\text { discomfort (vs 9\%); } \\
54 \% \text { gaseousness } \\
\text { (vs } 19 \%) ; 34 \% \\
\text { bloating (vs 5\%); } \\
\text { 24\% belching (vs } \\
\text { 9\%); } 16 \% \text { reflux (vs } \\
\text { 5\%) }\end{array}$ & 412 & $\begin{array}{l}\text { Children with ASD } \\
\text { diagnosis attending } \\
\text { autism clinics in } 2 \\
\text { cities in } \\
\text { northeastern US }\end{array}$ & $\begin{array}{l}43 \text { healthy aged- } \\
\text { matched siblings }\end{array}$ & $\begin{array}{l}\text { Questionnaires to } \\
\text { patients at autism } \\
\text { clinic, supplemented } \\
\text { by interviews with } \\
\text { parents of } 116 \text { of } 412 \\
\text { patients }\end{array}$ \\
\hline Parracho et al ${ }^{23}$ (2005) & $\begin{array}{l}91.4 \% \text { (vs } 25 \% \text { in } \\
\text { siblings and } 0 \% \\
\text { in unrelated } \\
\text { healthy children } \\
{[P<.05] \text { vs all }} \\
\text { controls) }\end{array}$ & $\begin{array}{l}\text { 75.6\% diarrhea; } 55.2 \% \\
\quad \text { gaseousness; } 46.6 \% \\
\text { abdominal pain; } \\
\text { 44.8\% constipation; } \\
\text { 43.0\% abnormal } \\
\text { feces }\end{array}$ & 58 & $\begin{array}{l}\text { Children with ASDs } \\
\text { aged 3-16 y }\end{array}$ & $\begin{array}{l}\text { Two control groups: } 12 \\
\text { siblings without ASDs } \\
\text { and } 10 \text { unrelated } \\
\text { healthy children }\end{array}$ & $\begin{array}{l}\text { Data obtained by } \\
\text { questionnaire }\end{array}$ \\
\hline Lightdale et al ${ }^{24}$ (2001) & & $\begin{array}{l}50 \% \text { loose stools or } \\
\text { diarrhea; } \sim 50 \% \\
\text { bloating, flatulence; } \\
33 \% \text { abdominal pain }\end{array}$ & 500 & Children with ASDs & & Parental reports \\
\hline Afzal et al ${ }^{25}$ (2003) & - & $\begin{array}{l}36 \% \text { moderate or } \\
\quad \text { severe constipation } \\
\text { (vs } 10 \%[P=.011] \text { ); } \\
54.4 \% \text { moderate or } \\
\text { severe rectosigmoid } \\
\text { loading (vs } 24.1 \% \\
{[P<.01] \text { ) }}\end{array}$ & 103 & $\begin{array}{l}\text { Children aged } \leq 18 \text { y } \\
\text { with formal ASD } \\
\text { diagnosis who were } \\
\text { referred to tertiary } \\
\text { pediatric } \\
\text { gastroenterology } \\
\text { service }\end{array}$ & $\begin{array}{l}29 \text { consecutive children } \\
\text { without ASDs } \\
\text { referred to } \\
\text { emergency } \\
\text { department, most } \\
\text { with abdominal pain }\end{array}$ & $\begin{array}{l}\text { Retrospective study of } \\
\text { abdominal } \\
\text { radiographs }\end{array}$ \\
\hline
\end{tabular}

GER indicates gastroesophageal reflux; MMR, measles, mumps, and rubella; RUPP, Research Units on Pediatric Psychopharmacology.

a Chronic inflammation of gastrointestinal tract (eg, ulcerative colitis and regional enteritis), celiac disease, food intolerance, and recurrent gastrointestinal symptoms (eg, diarrhea, colic, or vomiting 3 times in 6 months).

${ }^{\mathrm{b}}$ Gastrointestinal problem was moderate when it caused some impairment or required intervention to prevent likely impairment.

${ }^{\mathrm{c}}$ Gastrointestinal problem was severe when it caused impairment and required intervention.

${ }^{\mathrm{a}}$ Chronic gastrointestinal dysfunction defined as diarrhea or unformed stools, constipation, gastroesophageal reflux, or bloating persisting for an estimate of $>6$ months.

e More than 4 weeks of daily painless recurrent passage of $\geq 3$ large unformed stools.

hypothesized a link between such deficits and increased gut permeability. ${ }^{13}$

The available literature has not confirmed the presence of abnormal gastrointestinal permeability in individuals with ASDs, and the presence of increased intestinal permeability has not been correlated with an underlying gastrointestinal disorder or neuropsychiatric manifestations. Studies to date have had methodologic limitations including small subject populations and poor controls; properly powered prospective studies with appropriate controls are needed.

\section{Statement 6}

Individuals with ASDs and gastrointestinal symptoms are at risk for problem behaviors. When patients with gastro- intestinal disorders present with behavioral manifestations, the diagnostic evaluation can be complex.

An emerging literature suggests that individuals with ASDs and gastrointestinal symptoms may be at higher risk for problem behaviors than those with ASDs who do not have gastrointestinal symptoms. ${ }^{32}$ Problem behaviors are recurrent behaviors that interfere 
with an individual's functioning; their occurrence often affects family and community members as well. Problem behaviors are the single most important factor in determining quality of life for individuals with ASDs and their caretakers. ${ }^{33}$ Vocal and motor behaviors, including problem behaviors such as self-injury and aggression, as well as overall changes in state of being (eg, sleep disturbance or irritability), may be behavioral manifestations of abdominal pain or discomfort in persons with ASDs (Table 2). ${ }^{14,15}$

The evaluation of individuals with ASDs and gastrointestinal symptoms can be complex. Sleep disturbances and the other problem behaviors mentioned above may indicate abdominal discomfort. In turn, abdominal discomfort, as well as other symptoms (constipation, flatulence, bloating, diarrhea, straining), may be manifestations of neurenteric dysregulation or IBS. A diagnosis of exclusion, IBS is difficult to distinguish from other underlying conditions without invasive testing. For the patient who is not losing weight, has no blood in the stool, and has normal findings on a complete blood count and urinalysis, evaluations are recommended in the order described in Table 3. No evidence-based guidelines are available to guide the evaluation. For this reason, primary care physicians, psychiatrists, psychologists, pediatricians, and gastroenterologists may need to work together to improve the evaluation and treatment of gastrointestinal symptoms in individuals with ASDs.

\section{Statement 7}

For a person with an ASD who presents for treatment of a problem behavior, the care provider should consider the possibility that a gastrointestinal symptom, particularly pain, is a setting event, that is, a factor that increases the likelihood that serious problem behavior (eg, self-injury, aggression) may be exhibited. Sudden and unexplained behavioral change can be the hallmark of underlying pain or discomfort. Behavioral treatment may be initiated as the possible concurrent medical illness is being investigated, diagnosed (or excluded), and treated, but the behavioral treatment should not substitute for medical investigation. The behavioral treatment plan should be developed, implemented, and changed as needed in collaboration with the medical caregivers who are leading the medical investigation.

Clinical practice guidelines for the management of ASDs have not included routine consideration of potential gastrointestinal problems. ${ }^{1,3-5}$ As previously noted, for individuals with ASDs, symptoms associated with gastrointestinal disorders, especially pain, may function as setting events for problem behaviors. ${ }^{34}$ In this context, a setting event is any gastrointestinal symptom that influences how a person will respond to a given environment. For example, the presence of pain (a gastrointestinal setting event) can result in simple daily tasks and routines being perceived by the child as much more aversive than would be the case if the child were healthy and free of pain. As a consequence, these tasks and routines now trigger bouts of severe problem behavior as the child attempts to escape from the now-aversive situation. Once the gastrointestinal condition has been treated successfully, it is likely that pain will diminish, the situation will be perceived as less aversive, and the child will, therefore, no longer be motivated to engage in problem behavior. A review of both gastrointestinal symptoms and behaviors clinically associated with gastrointestinal problems (see Tables 2 and 3 ), along with other potential sources of pain and discomfort (such as ear, dental, urologic, musculoskeletal, and cutaneous problems), should be incorporated into the clinical behavioral assessment.

The presence of gastrointestinal symptoms and/or related behaviors (Table 3), regardless of whether they are clearly temporally related to problem behavior, should be considered a strong and urgent indication for medical investigation. Clinical judgment will determine if medical investigation should precede or occur concurrently with behavioral and/or psychopharmacologic intervention; the latter, however, should never substitute for medical investigation. Clearly, reliable biomarkers of gastrointestinal function are needed to identify those individuals who are highly likely to have conditions that may respond to medical or surgical intervention. Until such biomarkers are shown to be helpful, clinicians with expertise in both medical and behavioral interventions should work together on an integrated care plan.

Recognition that abdominal pain and discomfort can function as a setting event has important implications for the treatment of problem behavior. ${ }^{15}$ First, time-consuming behavioral treatments that address only psychosocial triggers and consequences for problem behavior may likely be ineffective. Behavioral treatments that promote means of communication in the affected individual may be more effective. For example, it would be extremely useful, from the standpoint of medical diagnosis, to teach a child to identify the location and type of pain that he or she is currently experiencing. ${ }^{35}$ Second, the individual can be taught skills for coping with task demands appropriately during moments of pain or discomfort, and psychosocial environments that have become aversive because of gastrointestinal pain can be restructured to attenuate 
their aversive properties. ${ }^{36,37}$ Third, if the gastrointestinal disorder is recognized and medical treatment is effective, the problem behaviors may diminish. When abdominal pain or discomfort is a setting event, psychotropic medications are likely to be ineffective and may even aggravate the problem if they have adverse gastrointestinal effects.

\section{Statement 8}

Education of caregivers and health care providers is necessary to impart knowledge of how to recognize typical and atypical signs and symptoms of gastrointestinal disorders in individuals with ASDs.

The clinical presentation of gastrointestinal disorders in individuals with ASDs may differ from that of individuals with typical development. For example, behavioral alterations can complicate the diagnosis of GERD in persons with compromised communication skills. Expert clinicians have observed that aggressive and selfinjurious behavior may be the primary clinical manifestations of GERD in individuals with ASDs, but these symptoms are frequently attributed to nonmedical causes. As a result, manifestations may go unrecognized as signs and symptoms of GERD and, importantly, may go untreated. Caregivers should be informed about atypical manifestations of gastrointestinal disorders. Greater awareness of this association by health care providers may result in these conditions being diagnosed and treated in more affected individuals. Additional research is needed to evaluate the usefulness of adding behavior to screening for gastrointestinal problems in persons with ASDs.

Educational programs designed to increase awareness of medical conditions that can go unrecognized because of atypical symptom presentation should be a priority at meetings of profes- sional societies such as the American Academy of Pediatrics, American Academy of Family Physicians, and National Association of Pediatric Nurse Practitioners.

\section{Statement 9}

Pediatricians and other primary care providers should be alert to potential nutritional problems in patients with ASDs. Evaluation by a nutritionist who is familiar with nutrition support for individuals with ASDs is recommended if caregivers raise concern about the patient's diet or if the patient exhibits selectivity of intake or is on a restricted diet.

Nutritional deficiencies have been reported in patients with ASDs, which is not surprising because of the narrow food preferences of many affected individuals and/or purported therapeutic diets that might be nutritionally inadequate. In a study of 36 children with ASDs, regardless of unrestricted or restricted diet, essential amino acid deficiencies consistent with poor protein nutrition occurred more frequently than in age- and gender-matched controls. $^{38}$ Low dietary intake of calcium and vitamin $D$ and iron deficiency have been implicated in compromised bone development and sleep disturbances, respectively, in children with ASDs receiving an unrestricted or restricted diet. ${ }^{39,40}$ Resources for general nutritional guidance are available that may be helpful for families. ${ }^{41-43}$

\section{Statement 10}

Primary care nutritional assessment for each person with an ASD should include (1) weight for height or BMI, (2) weight for age, (3) height for age, and (3) any marked changes in growth rate (percentiles over time).

It is recommended that pediatricians routinely monitor anthropometry as part of the evaluation of children with ASDs. Abnormalities in nutritional sta- tus (wasting, stunting) or changes in growth rate should alert the clinician to inadequate growth and the possibility of inadequate caloric intake or poor nutritional quality of the diet, malabsorption, or maldigestion. Any child whose growth is of concern should be referred to a nutritionist, preferably one who is familiar with nutritional support for individuals with ASDs.

In addition to nutritional inadequacy, children with ASDs have the potential to be obese. In a retrospective review of charts from 1992 to 2003 in children aged 3 to 18 years with ASDs, the prevalence rates of at risk for overweight (BMI $\geq 85$ th percentile) and overweight (BMI $\geq 95$ th percentile) were $35.7 \%$ and $19.0 \%$, respectively. ${ }^{44}$ These prevalence data are similar to rates in children aged 6 to 19 years in the general population of $31.0 \%$ and $16.0 \%$ for at risk for overweight and overweight, respectively, in 19992002. ${ }^{45}$ However, children with ASDs in the 12- to 19-year age range were reported to have $80 \%$ and $50 \%$ rates of being at risk for overweight and overweight, respectively, compared with $30.9 \%$ and $16.1 \%$, respectively, in the general population. ${ }^{44}$

\section{Statement 11}

Anecdotal reports have suggested that there may be a subgroup of individuals with ASDs who respond to dietary intervention. Additional data are needed before pediatricians and other professionals can recommend specific dietary modifications.

Dietary modifications such as removal of milk for symptoms of lactose intolerance may be approached empirically, as with any other pediatric patient with consistent symptoms. The data on the value of specific diets being effective in the treatment of individuals with ASDs are difficult to assess. Many dietary modifications are believed to have a beneficial outcome, al- 
though placebo effects are likely to be high in this setting. The few studies in the literature are difficult to interpret without adequate control groups.

\section{Statement 12}

Available research data do not support the use of a casein-free diet, a gluten-free diet, or combined glutenfree, casein-free (GFCF) diet as a primary treatment for individuals with ASDs.

Few studies have examined the effects of a casein-free diet, a gluten-free diet, or combined GFCF diet on the behavior of individuals with ASDs. To our knowledge, only 1 double-blind placebocontrolled study has been published to date. ${ }^{46}$

In this double-blind crossover trial of GFCF or typical diet in 15 children with ASDs, there were no differences in measures of severity of ASD symptoms, communication, social responsiveness, and urinary peptide levels after 12 weeks. ${ }^{46}$ Nevertheless, after being informed of the results, 9 parents wanted to continue the diet and reported positive subjective clinical changes while their child was on the GFCF diet. Study limitations included the small sample size and heterogeneity, concerns about compliance and possible dietary infractions by study subjects, and lack of a direct observational outcome measure.

Parents need information to help plan a balanced diet within the restrictions imposed by the chosen diet. Given the real hardships associated with implementation of a strict GFCF diet, additional studies are needed to assess risk factors and possible markers that identify individuals who might benefit from these diets. The panel emphasized that parents and care providers should agree on objective measures, which ideally are to be evaluated by blinded observers, to assess the intervention effect as well as a reasonable time frame before embarking on restrictive or unusual diets. The current literature does not permit a recommendation as to the length of a trial of dietary intervention. In the absence of data, any trial will need to be long enough to ensure that variability in behavior is not responsible for the perceived diet response.

\section{Statement 13}

For patients with ASDs, a detailed history should be obtained to identify potential associations between allergen exposure and gastrointestinal and/or behavioral symptoms.

It has been estimated that $25 \%$ to $65 \%$ of children in westernized societies have evidence of allergen sensitization, with food allergy present in $6 \%$ to $8 \%$ of infants and young children and $\sim 4 \%$ of adolescents and adults. It is assumed that a similar proportion of children with ASDs exhibit allergic disorders. ${ }^{47-49}$ Table 5 lists symptoms associated with immune-mediated gastrointestinal food allergies as well as suggested diagnostic approaches. ${ }^{50}$ The patient's parents, teachers, or other caretakers are an important source of information, because they are in a position to observe an association between exposure and the person's response.

\section{Statement 14}

Standardized definitions of adverse reactions to foods would be helpful in discussions with patients/providers. These definitions also should be used in studies of adverse food reactions in individuals with ASDs.

Health care providers can reduce the potential for misunderstanding by defining terms with patients and their families early in the evaluation process and reviewing with them the different types of adverse reactions to foods. In doing so, they establish a framework for discussions about whether the diagnosis is food allergy, another type of adverse reaction to a food, or some other entity unrelated to food ingestion.

In a logical scheme developed for categorization of food-induced reactions according to mechanism, an adverse reaction to a food is the general term used to refer to any unpleasant reaction that occurs as a result of food ingestion..$^{51}$ An adverse reaction to a food may be toxic or nontoxic. ${ }^{52}$ In toxic reactions the symptoms are caused by a toxin synthesized by the food or by an organism or substance that contaminated the food. Although sensitivity to different toxins may vary from person to person, a characteristic of toxic reactions is that they occur in virtually every person who ingests enough of the food that contains the toxin. ${ }^{51}$

Nontoxic reactions are further categorized into food intolerance or food allergy, depending on whether the immune system is the primary cause of the reaction. ${ }^{52}$ Reactions in which the immune system is not involved are categorized as examples of food intolerance. Categories of food intolerance include metabolic, pharmacologic, and idiosyncratic reactions. Individuals are more likely to experience metabolic reactions to foods if they are malnourished or ill, take certain medications, or have acquired or inherited metabolic disorders. Pharmacologic food reactions occur after the ingestion of foods that contain pharmacologically active ingredients. Idiosyncratic reactions resemble allergic reactions to foods but are not mediated by the immune system and result from a quantitatively abnormal response to a food or food additive that is not caused by a pharmacologic or physiologic effect of the food.

Food allergy is the term used to refer to nontoxic reactions to foods that are mediated by the immune system..$^{52} \mathrm{Al}$ lergic reactions to foods are further 
TABLE 5 Symptoms Associated With Immune-Mediated Gastrointestinal Food Allergies and Suggested Diagnostic Approaches

\begin{tabular}{|c|c|c|c|}
\hline Disorder & Mechanism & Symptoms & Diagnostic Approach \\
\hline $\begin{array}{l}\text { Pollen-food allergy syndrome (oral } \\
\text { allergy syndrome) }\end{array}$ & IgE mediated & $\begin{array}{l}\text { Mild pruritus, tingling, and/or angioedema } \\
\text { of the lips, palate, tongue, or oropharynx; } \\
\text { occasional sensation of tightness in the } \\
\text { throat and rarely systemic symptoms }\end{array}$ & $\begin{array}{l}\text { Clinical history and positive SPT responses } \\
\text { to relevant food proteins (prick-plus- } \\
\text { prick method); } \pm \text { oral challenge: } \\
\text { positive with fresh food, negative with } \\
\text { cooked food }\end{array}$ \\
\hline Gastrointestinal "anaphylaxis" & IgE mediated & $\begin{array}{l}\text { Rapid onset of nausea, abdominal pain, } \\
\text { cramps, vomiting, and/or diarrhea; other } \\
\text { target organ responses (ie, skin, } \\
\text { respiratory tract) often involved }\end{array}$ & $\begin{array}{l}\text { Clinical history and positive SPT responses } \\
\text { or RAST results; } \pm \text { oral challenge }\end{array}$ \\
\hline Allergic eosinophilic esophagitis & $\begin{array}{l}\text { IgE mediated and/or cell } \\
\text { mediated }\end{array}$ & $\begin{array}{l}\text { GER or excessive spitting up or emesis, } \\
\text { dysphagia, intermittent abdominal pain, } \\
\text { irritability, sleep disturbance, failure to } \\
\text { respond to conventional antireflux } \\
\text { medications }\end{array}$ & $\begin{array}{l}\text { Clinical history, SPTs, endoscopy and } \\
\text { biopsy, elimination diet, and challenge }\end{array}$ \\
\hline $\begin{array}{l}\text { Allergic eosinophilic } \\
\text { gastroenteritis }\end{array}$ & $\begin{array}{l}\text { IgE mediated and/or cell } \\
\text { mediated }\end{array}$ & $\begin{array}{l}\text { Recurrent abdominal pain, irritability, early } \\
\text { satiety, intermittent vomiting, FTT and/or } \\
\text { weight loss, peripheral blood eosinophilia } \\
\text { (in } 50 \% \text { ) }\end{array}$ & $\begin{array}{l}\text { Clinical history, SPTs, endoscopy and } \\
\text { biopsy, elimination diet, and challenge }\end{array}$ \\
\hline $\begin{array}{l}\text { Food protein-induced } \\
\text { proctocolitis }\end{array}$ & Cell mediated & $\begin{array}{l}\text { Gross or occult blood in stool; typically } \\
\text { thriving; usually presents in first few } \\
\text { months of life }\end{array}$ & $\begin{array}{l}\text { Negative SPT responses; elimination of } \\
\text { food protein } \rightarrow \text { clearing of most } \\
\text { bleeding in } 72 \mathrm{~h} \text {; } \pm \text { endoscopy and } \\
\text { biopsy; challenge induces bleeding } \\
\text { within } 72 \mathrm{~h}\end{array}$ \\
\hline $\begin{array}{l}\text { Food protein-induced } \\
\text { enterocolitis }\end{array}$ & Cell mediated & $\begin{array}{l}\text { Protracted vomiting and diarrhea ( } \pm \text { blood) } \\
\text { not infrequently with dehydration; } \\
\text { abdominal distention; FTT; vomiting } \\
\text { typically delayed } 1-3 \text { hours after feeding }\end{array}$ & $\begin{array}{l}\text { Negative SPT responses; elimination of } \\
\text { food protein } \rightarrow \text { clearing of symptoms in } \\
24-72 \mathrm{~h} \text {; challenge } \rightarrow \text { recurrent } \\
\text { vomiting within } 1-2 \mathrm{~h}, \sim 15 \% \text { have } \\
\text { hypotension }\end{array}$ \\
\hline $\begin{array}{l}\text { Food protein-induced enteropathy } \\
\text { celiac disease (gluten-sensitive } \\
\text { enteropathy) }\end{array}$ & Cell mediated & $\begin{array}{l}\text { Diarrhea or steatorrhea, abdominal } \\
\text { distention and flatulence, weight loss or } \\
\text { FTT, } \pm \text { nausea and vomiting, oral ulcers }\end{array}$ & $\begin{array}{l}\text { Endoscopy with biopsy of duodenum while } \\
\text { on a gluten-containing diet; IgA; tissue } \\
\text { transglutaminase; antiendomysial } \\
\text { antibody; if IgA deficient, IgG tissue } \\
\text { transglutaminase should be measured }\end{array}$ \\
\hline
\end{tabular}

FTT, failure to thrive; GER, gastroesophageal reflux; Ig, immunoglobulin; RAST, radioallergosorbent test; SPT, skin-prick test.

Adapted from with permission from the American Academy of Allergy Asthma \& Immunology from Sampson HA. J Allergy Clin Immunol. 2003;111(2 suppl):S540-S547.

categorized as mediated by immunoglobulin E (IgE), non-lgE mediated, or combined (both IgE- and non-lgEmediated mechanisms are implicated). ${ }^{49}$ Disorders caused by IgEmediated reactions to foods typically involve the gastrointestinal tract, the skin, and the respiratory tract either alone or in combination. For example, gastrointestinal anaphylaxis presents with cramping abdominal pain, nausea, and vomiting that occurs within minutes to hours of ingestion of the offending food and is often accompanied by cutaneous or respiratory symptoms. IgE-mediated cutaneous symptoms include acute urticaria, angioedema, generalized pruritus, and flushing, whereas respiratory disorders associated with lgE-mediated reactions to foods include acute rhinoconjunctivitis and acute-onset bronchospasm. The most severe form of an IgE-mediated allergic reaction to a food is anaphylaxis involving multiple organ systems. ${ }^{53}$

Non-IgE-mediated allergic reactions to foods may be cell mediated. Examples that involve the gastrointestinal tract include food protein-induced syndromes such as food protein-induced enterocolitis, food protein-induced proctocolitis, and food protein-induced enteropathy syndromes. ${ }^{54,55}$ These disorders are seen primarily in infants or young children who present with abdominal complaints such as vomiting, cramping abdominal pain, diarrhea, and occasionally blood in the stool. Celiac disease, which results from sensitivity to gliadin (found in grains such as wheat, rye, and barley), is another example of a non-lgE-mediated gastrointestinal reaction to a food. ${ }^{56,57}$ Dermatitis herpetiformis and contact dermatitis are examples of cutaneous non-lgEmediated reactions to food. Mixed IgEand cell-mediated allergic reactions to foods are exemplified by eosinophilic gut disorders, such as eosinophilic esophagitis and allergic eosinophilic gastroenteritis, or potentially other entities such as atopic dermatitis or asthma. ${ }^{58}$

The potential for a food aversion should be considered in patients with ASDs. Aversion may be present because of a previous noxious event that occurred after ingestion of a specific 
food. The aversion to the specific food may then be generalized to a broader food category. An example is a child who becomes ill after eating a tomato; a child with an ASD who has that experience may subsequently avoid all red foods. This aspect of food intolerance is often overlooked in the search for the cause of an individual's refusal of a specific food.

\section{Statement 15}

For patients with ASDs, a detailed history (including personal history of allergic disease, dietary history, and family history) and physical examination should be performed to accurately identify potential comorbid allergic disease.

A comprehensive history and physical examination always provide important information for the clinician who is evaluating the person with an ASD and possibly co-occurring allergies. A positive history of allergic disease in parents and siblings is a significant risk factor, placing the person at higher risk for the development of allergies. The typical pattern of allergen sensitization, often referred to as the "atopic march," begins with sensitization to food allergens and/or eczema within the first 2 years of life, followed by sensitization to inhalant allergens manifested by allergic rhinitis, animal dander sensitivity, and/or allergen-driven asthma. Many children outgrow IgEmediated reactions to foods such as milk, egg, soy, and grains as they age, although most individuals who are sensitized to peanuts, tree nuts, fish, and shellfish remain allergic. Non-IgE-mediated reactions to foods such as allergic proctocolitis and food protein-induced enterocolitis are outgrown in the first few years of life, whereas celiac disease is lifelong. Combined IgE- and non-lgE-mediated allergic reactions to foods such as eosinophilic esophagitis and eosino- philic gastroenteritis are often long lived, with symptoms that wax and wane.

Older children who present for allergic evaluation are unlikely to have allergic colitis, a non-lgE-mediated condition that is often outgrown by 3 or 4 years of age in typically developing children. In individuals with ASDs, some experts have commented that resolution of a non-IgE-mediated condition may be delayed, possibly related to underdiagnosis at a young age. There are no data to support this speculation.

Because allergic diseases are common and individuals with ASDs may have atypical presentations or diffculty verbalizing complaints, it is important for caregivers to be vigilant in monitoring symptoms and looking for signs of allergic disease. If the presence of allergic disease is suggested by the history or physical examination, patients with ASDs should undergo appropriate allergy testing (eg, skin testing, measurement of allergen-specific IgE levels, elimination diets, food challenges) and gastrointestinal evaluation (including laboratory testing and endoscopy, if indicated), as would be done for patients without ASDs.

\section{Statement 16}

Involvement of specialists (allergists, gastroenterologists, dietitians, and feeding therapists) for the management of individuals with ASDs may be beneficial.

The management of uncomplicated gastrointestinal disorders, such as constipation or GERD, in individuals with ASDs can be initiated and followed by the pediatrician or other primary health care provider. Patients who are unresponsive to standard care may benefit from a referral to a gastroenterologist. The panel emphasized that specialist referral should be undertaken only after a patient has not responded to standard treatment di- rected by the primary health care provider.

Similarly, patients with ASDs who have allergic disease can receive effective care under the supervision of a pediatrician or other primary care provider. Involvement of an allergist is recommended for patients with multiple allergies or complex allergic disease. Working with a dietitian to optimize nutrition is helpful, because these patients often have specific food preferences and limited diets or are on supplements that should be critically evaluated from a nutritional standpoint. A knowledgeable feeding therapist should be consulted when feeding disorders are suspected or the patient is difficult to feed. The potential benefits of an allergy program with input from experts in other areas include not only reduction in symptoms of allergic disease but also fewer medication adverse effects and, in some instances, an improvement in behavior.

\section{Statement 17}

Immunologic aberrations have been reported in individuals with ASDs. However, a direct cause-and-effect relationship between immune dysfunction and ASDs has yet to be proven.

There has been research to suggest that immune responses can influence neurodevelopment and that significant immunologic alterations may play a key pathogenic role in some individuals with ASDs. Two lines of research are promising: (1) dysregulation of cytokine production; and (2) the effect of maternal autoantibodies during early neurodevelopment.

Researchers in a number of laboratories have described intestinal inflammatory changes in individuals with ASDs. ${ }^{59-61}$ A few studies have suggested that activation of circulating lymphocytes and monocytes may lead to dysregulated cytokine production. ${ }^{62-66}$ Some investigators have speculated 
that increased peripheral cytokine levels may act directly on the central nervous system (CNS) or may trigger a CNS-mediated inflammatory response via glial cells. In turn, these actions could affect neurodevelopment or directly elicit autistic behaviors (reviewed by Ashwood and Wakefield ${ }^{67}$ ). Other researchers have observed increased production of cytokines from the innate immune system in the plasma and CNS, including interleukin 6 (IL-6), tumor necrosis factor $\alpha$ (TNF$\alpha$ ), and macrophage chemoattractant protein 1 (MCP-1). ${ }^{63,68,69}$

An increase in autoimmune disorders has been reported in the families of individuals with ASDs. The findings of (1) a family history of autoimmune disease and (2) antibrain antibodies suggest that, in some individuals with ASDs, autoantibodies that target the CNS may be related to the neurobiology of the disorder. ${ }^{70-74}$

Immunoprotective maternal IgG antibodies and autoantibodies that react to fetal "self" proteins have been shown to cross the placenta. ${ }^{75}$ In a recent study, reactivity to human fetal brain protein, but not adult brain protein, was observed with antibodies from 7 of 61 (11.5\%) mothers of children with ASDs. ${ }^{76}$ In contrast, immunoreactivity was observed in neither the mothers of children with typical development nor the mothers of children with developmental delays but no ASDs. In a population-based study by the same group with samples taken during gestation, a pattern of maternal antibody reactivity to fetal brain protein (simultaneous reactivity to 39and 73-kDa molecular weight bands) was reported only for mothers of children with early-onset ASDs. ${ }^{77}$ More recently, introduction of maternal IgG in a Rhesus monkey model resulted in profound behavioral changes in the offspring. ${ }^{78}$ These clinical and animal observations are of potential interest in understanding a possible mechanism for the behavioral changes observed in ASDs. At present, their clinical relevance is speculative.

We are now able to accurately define immune status in individuals with ASDs. Well-defined studies are needed using larger sample sets and age- and geographically matched controls, with extensive immune analysis, to determine the precise relationship of immune dysfunction to clinical symptoms.

\section{Statement 18}

The role of immune responses in the pathogenesis of gastrointestinal disorders in individuals with ASDs warrants additional investigation.

A few studies have suggested a relationship between gastrointestinal inflammation and gastrointestinal symptoms associated with ASDs. The gastrointestinal tract is the largest immune organ in the body, containing up to $80 \%$ of Ig-producing cells in the body. In children with ASDs, immunohistochemistry and flow-cytometry studies have consistently shown marked panenteric infiltration of lymphocytes and eosinophils in the gut mucosa. $59,61,79,80$ Torrente et al ${ }^{61,80}$ suggested an autoimmune component to the inflammatory response (co-localized deposition of IgG and complement C1q on the surface epithelium of the gastrointestinal tract). These studies suggest an underlying chronic inflammatory process in some individuals with ASDs and co-occurring gastrointestinal disturbances, characterized by NLH, enterocolitis, and mucosal infiltration by immune cells along the length of the gastrointestinal tract. These findings should be considered preliminary and will require confirmation.

\section{Statement 19}

The role of gut microflora in the pathogenesis of gastrointestinal disorders in individuals with ASDs is not well understood.

The microbiological ecosystem of the gut is complex and poorly understood but likely plays a significant role in both health and disease. Few researchers, however, have attempted to critically examine the relationship of gut microflora to ASDs. Future studies will require molecular approaches aimed at identification and quantification of microbial species. If an association is identified, it may lead to novel treatment trials. Careful selection of study subjects will be important for controlling for antimicrobial exposure, diet, and other factors.

It should be noted that empirical antibiotic and antifungal therapy in patients with ASDs is not recommended. Clinicians should obtain an abnormal culture result from a duodenal aspirate or abnormal stool culture before starting any treatment designed to alter intestinal flora.

\section{Statement 20}

Given the heterogeneity of persons with ASDs and the many inconsistent research findings regarding ASDs, it is imperative that the phenotype (biological, clinical, and behavioral features) of future study subjects be well defined. This will help to clarify the underlying pathophysiology and the clinical aspects of the disorder and guide focused evaluations and treatments.

A number of factors make the generalization of study findings difficult. Individuals with ASDs share a common behavioral diagnosis and, although at present we are unable to establish an etiologic diagnosis for most cases of ASDs, we are nonetheless aware of numerous uncommon or rare causes of this behaviorally defined condition. It is likely, therefore, that different pathogenic mechanisms underlie ASDs in individuals who have received this diagnosis. Consequently, future 
studies relating to diagnostic, pathophysiologic, and therapeutic aspects of ASDs should endeavor to characterize in detail the clinical, behavioral, metabolic, genetic, and imaging phenotypes of the subjects to the extent possible.

\section{Statement 21}

Studies of gastrointestinal disorders in ASDs should include genetic testing for all participants.

Future research studies to examine gastrointestinal function in people with ASDs should include characterization of the genotype. Guidelines for the genetic evaluation of individuals with ASDs have been published by the American College of Medical Genetics. ${ }^{81}$ Our recommendations include consideration of determinations of chromosomal microarray analysis, mutation analysis of the FMR1 gene (to evaluate for fragile $X$ syndrome), mutation analysis of the MECP2 gene in females, as well as mutation analysis of clinically relevant candidate genes and selected metabolic testing based on the clinical and family histories and physical examination.

\section{Statement 22}

Prevalence and characterization of specific gastrointestinal symptoms should be examined in well-defined genetic syndromes with high rates of ASDs.

It is recommended that gastrointestinal disorders be studied in individuals with genetically well-defined disorders with which ASD rates are high. Such disorders are rare and include Rett, Smith-Lemli-Opitz, and fragile $X$ syndromes. There have been minimal published data regarding gastrointestinal dysfunction in these and other monogenic or chromosomal disorders that are strongly associated with ASDs.

Gastrointestinal dysfunction in persons with ASDs and a monogenic dis- order could result from a direct effect of the mutated gene on a specific gut function. Alternatively, abnormal neurologic function rather than an intrinsic, genetically programmed abnormality within the gastrointestinal tract could be the basis of disturbed gastrointestinal function. Differentiating between these pathophysiologic categories is difficult at present.

Detailed description of gastrointestinal dysfunction in individuals with ASDs and defined genetic conditions will increase our knowledge of the natural histories of these conditions and ideally translate to improved clinical care. It may also provide insight into the pathogenetic basis of the gastrointestinal dysfunction with these conditions. Lessons learned about gastrointestinal abnormalities from monogenic conditions will likely have relevance for similar gastrointestinal abnormalities that occur not only in individuals with idiopathic ASDs but also in individuals without ASDs. Recent data regarding the MET gene are provocative in this regard. ${ }^{82}$

\section{Statement 23}

Clinical trials of treatment of gastrointestinal symptoms should include banking of DNA samples.

Investigators are strongly encouraged to obtain blood samples for banking of DNA in their research protocols. An unknown but potentially large fraction of patients may have specific mutations as the cause of their ASDs. The value of the research will be significantly greater if causative mutations are identified in some of the subjects and the data reanalyzed in light of this information.

\section{CONCLUSIONS}

Medical disorders, including gastrointestinal problems, occur commonly in individuals with ASDs, but because symptoms may be atypical, these med- ical conditions may be undiagnosed. Whether the prevalence is higher than in the general population is not known with certainty, because prospective well-controlled studies are unavailable. Many parents and care providers have observed and reported improvements in problem behaviors with nutritional or medical interventions. Some of these therapies are based on purely observational reports; many are based on studies that may have reached erroneous conclusions because of recruitment bias, lack of validated or standardized outcomes, or inadequate controls. In this document we focused on gastrointestinal disorders and related conditions including allergy, inflammation, metabolic disease, genetics, and nutrition.

The care of individuals who are nonverbal or have difficulties in communication or who display self-injurious or other problem behaviors presents special challenges. Nevertheless, the approach to evaluation and diagnosis of possible underlying medical conditions, in particular gastrointestinal disorders, should be no different from the standard of care for persons without ASDs. Management of cooccurring gastrointestinal problems in individuals with ASDs usually begins with the primary care provider and may eventually warrant multidisciplinary consultation.

Anecdotal reports that restricted diets may ameliorate symptoms of ASDs in some children have not been supported or refuted in the scientific literature, but these data do not address the possibility that there exists a subgroup of individuals who may respond to such diets. Professional supervision of restricted diets is recommended to prevent nutritional inadequacies.

Future research is expected to clarify the role of metabolic disorders, allergic/toxic reactions, immune dysregulation, and inflammatory changes in 
TABLE 6 Key Take-Away Messages

Individuals with ASDs whose families report gastrointestinal symptoms warrant a thorough gastrointestinal evaluation.

All of the common gastrointestinal conditions encountered by individuals with typical neurologic development are also present in individuals with ASDs.

The communication impairments characteristic of ASDs may lead to unusual presentations of gastrointestinal disorders, including sleep disturbances and problem behaviors

Caregivers and health care professionals should be alert to the presentation of atypical signs of common gastrointestinal disorders in patients with ASDs.

If a person with an ASD is on a restricted diet, professional supervision can help to identify and treat nutritional inadequacy.

Integrating behavioral and biomedical approaches can be advantageous in conceptualizing the role of pain as a setting event for problem behavior, facilitating diagnosis, and addressing residual pain symptoms to enhance quality of life.

Genetic assays should be included as part of the data to be collected in research protocols.

At present, there are inadequate data to establish a causal role for intestinal inflammation, increased intestinal permeability, immunologic abnormalities, or food allergies in ASDs.

the etiology of gastrointestinal disturbances in individuals with ASDs. Whether unique genetic, metabolic, or physiologic conditions exist and are specific to ASDs remains to be determined. Accrual of new knowledge will advance our approach to the management of ASDs and co-occurring medical conditions. Recognition that problem behaviors might indicate an underlying medical condition will facil- itate diagnosis and treatment and ultimately improve the quality of life for many persons with ASDs. This expert panel has addressed considerations in the diagnostic evaluation of gastrointestinal symptoms in individuals with ASDs that may lead to effective treatment options, with the hope that patients will have better access to enlightened care. Important take-away messages are summarized in Table 6 , and areas that are in need of new knowledge are identified in Table 7.

\section{ACKNOWLEDGMENTS}

The meeting and consensus report were sponsored by the Autism Forum. The forum's goal in this initiative is to establish best practices for the care of co-occurring medical conditions that may affect the developmental outcome of persons with ASDs. Autism Forum programs are developed under the guidance of the Northwest Autism Foundation and in association with, and support of, the Autism Research Institute, Autism Society of America, and Easter Seals Oregon.

Dr Carr passed away before publication of this supplement. He was an enthusiastic and articulate contributor whose comments were enlightening and greatly improved the manuscript. We shall miss his passion and deep commitment to improving the lives and quality of care of people with autism spectrum disorders.

TABLE 7 Areas in Need of New Knowledge

\begin{tabular}{|c|c|c|}
\hline Research Objective & Recommendation & Statement No. \\
\hline $\begin{array}{l}\text { Determine prevalence of gastrointestinal disorders in } \\
\text { individuals with ASDs }\end{array}$ & $\begin{array}{l}\text { Prospective multicenter studies; population-based studies; subjects with } \\
\text { well-documented diagnosis of ASD by accepted classification } \\
\text { methods; use of validated instruments and outcome measures }\end{array}$ & 3 \\
\hline $\begin{array}{l}\text { Develop screen for gastrointestinal disorders in } \\
\text { individuals with ASDs that can be used by primary } \\
\text { care and other providers }\end{array}$ & $\begin{array}{l}\text { Prospective multicenter studies; validation by gastrointestinal } \\
\text { specialists }\end{array}$ & 2,7 \\
\hline $\begin{array}{l}\text { Identify behaviors associated with gastrointestinal pain/ } \\
\text { distress in persons with ASDs }\end{array}$ & $\begin{array}{l}\text { Prospective multicenter studies; evaluation of behavioral items as useful } \\
\text { additions to screens for gastrointestinal problems in persons with } \\
\text { ASDs; inclusion of treatment-responsive measures of behavior in } \\
\text { research trials of treatments for gastrointestinal problems }\end{array}$ & 2,7 \\
\hline $\begin{array}{l}\text { Evaluate whether dietary restriction is efficacious for } \\
\text { individuals with ASDs }\end{array}$ & Adequately powered randomized, controlled trial & 11 \\
\hline $\begin{array}{l}\text { Identify role of abnormal gastrointestinal permeability in } \\
\text { neuropsychiatric manifestations of ASDs }\end{array}$ & Prospective studies; properly powered and controlled & 5 \\
\hline $\begin{array}{l}\text { Determine relationship of immune dysfunction to clinical } \\
\text { symptoms that present in patients with ASDs }\end{array}$ & $\begin{array}{l}\text { Well-defined studies; large sample sets; age-matched and geographically } \\
\text { matched controls; extensive analysis of immune function }\end{array}$ & 17 \\
\hline $\begin{array}{l}\text { Determine if alteration in gut microflora is associated } \\
\text { with either gastrointestinal or neurobehavioral } \\
\text { symptoms in patients with ASDs }\end{array}$ & $\begin{array}{l}\text { Use high through-put molecular approaches to identify and quantify } \\
\text { microbial species; selection criteria to control for antimicrobial } \\
\text { exposure and diet }\end{array}$ & 19 \\
\hline $\begin{array}{l}\text { Clarify underlying pathophysiology and clinical aspects } \\
\text { of ASDs }\end{array}$ & $\begin{array}{l}\text { Detailed description of phenotype (biological, clinical, and behavioral } \\
\text { features) of study subjects }\end{array}$ & 20 \\
\hline $\begin{array}{l}\text { Characterize genotype of individuals with ASDs and } \\
\text { gastrointestinal disorders }\end{array}$ & $\begin{array}{l}\text { Include genetic testing for all study subjects; conduct studies in subjects } \\
\text { with well-defined genetic syndromes with high rates of ASDs }\end{array}$ & 21,22 \\
\hline $\begin{array}{l}\text { Identify genetic mutations that may be possible } \\
\text { underlying causes of ASDs }\end{array}$ & Obtain blood samples from study subjects for banking of DNA & 23 \\
\hline
\end{tabular}




\section{REFERENCES}

1. Johnson CP, Myers SM; American Academy of Pediatrics, Council on Children With Disabilities. Identification and evaluation of children with autism spectrum disorders. Pediatrics. 2007;120(5):1183-1215

2. Kuehn BM. CDC: autism spectrum disorders common. JAMA. 2007;297(9):940

3. Volkmar F, Cook EH Jr, Pomeroy J, Realmuto G, Tanguay P. Practice parameters for the assessment and treatment of children, adolescents, and adults with autism and other pervasive developmental disorders. American Academy of Child and Adolescent Psychiatry Working Group on Quality Issues [published correction appears in JAm Acad Child Adolesc Psychiatry. 2000;39(7):938]. J Am Acad Child Adolesc Psychiatry. 1999; 38(12 suppl):32S-54S

4. Filipek PA, Accardo PJ, Ashwal S, et al. Practice parameter: screening and diagnosis of autism: report of the Quality Standards Subcommittee of the American Academy of Neurology and the Child Neurology Society. Neurology. 2000;55(4):468-479

5. Myers SM, Johnson CP; American Academy of Pediatrics, Council on Children With Disabilities. Management of children with autism spectrum disorders. Pediatrics. 2007; 120(5):1162-1182

6. Guyatt FH, Oxman AD, Vist GE, et al; GRADE Working Group. GRADE: an emerging consensus on rating quality of evidence and strength of recommendations. BMJ. 2008; 336(7650):924-926

7. BMJ Clinical Evidence. What is GRADE? Available at: http://clinicalevidence.bmj.com/ ceweb/about/about-grade.jsp. Accessed July 26, 2008

8. Atkins D, Best D, Briss PA, et al; GRADE Working Group. Grading quality of evidence and strength of recommendations. BMJ. 2004; $328(7454): 1490$

9. Rudolph CD, Mazur LJ, Liptak GS, et al; North American Society for Pediatric Gastroenterology and Nutrition. Guidelines for evaluation and treatment of gastroesophageal reflux in infants and children: recommendations of the North American Society for Pediatric Gastroenterology and Nutrition. J Pediatr Gastroenterol Nutr. 2001;32 (suppl 2):S1-S31

10. American Academy of Pediatrics, Subcommittee on Chronic Abdominal Pain. Chronic abdominal pain in children. Pediatrics. 2005;115(3):812-815

11. Di Lorenzo C, Colletti RB, Lehmann HP, et al; American Academy of Pediatrics Subcommittee; NASPGHAN Committee on Chronic Abdominal Pain. Chronic abdomi- nal pain in children: a technical report of the American Academy of Pediatrics and the North American Society for Pediatric Gastroenterology, Hepatology and Nutrition. $\checkmark$ Pediatr Gastroenterol Nutr. 2005;40(3): 249-261

12. Constipation Guidelines Committee of the North American Society for Pediatric Gastroenterology, Hepatology, and Nutrition. Evaluation and treatment of constipation in infants and children: recommendations of the North American Society for Pediatric Gastroenterology, Hepatology, and Nutrition. J Pediatr Gastroenterol Nutr. 2006; 43(3):e1-e13

13. Horvath K, Perman JA. Autism and gastrointestinal symptoms. Curr Gastroenterol Rep. 2002;4(3):251-258

14. McAtee M, Carr EG, Schulte C, Dunlap G. A contextual assessment inventory for problem behavior: initial development. J Positive Behav Interv. 2004;6(3):148-165

15. Carr EG, Owen-DeSchryver JS. Physical illness, pain, and problem behavior in minimally verbal people with developmental disabilities. J Autism Dev Disord. 2007;37(3): 413-424

16. Black C, Kaye JA, Jick H. Relation of childhood gastrointestinal disorders to autism: nested case-control study using data from the UK General Practice Research Database. BMJ. 2002;325(7361):419-421

17. Taylor B, Miller E, Lingam R, Andrews N, Simmons A, Stowe J. Measles, mumps, and rubella vaccination and bowel problems or developmental regression in children with autism: population-based study. BMJ. 2002; 324(7334):393-396

18. Fombonne E, Chakrabarti S. No evidence for a new variant of measles-mumps-rubellainduced autism. Pediatrics. 2001;108(4). Available at: www.pediatrics.org/cgi/ content/full/108/4/e58

19. Nikolov RN, Bearss KE, Lettinga J, et al. Gastrointestinal symptoms in a sample of children with pervasive developmental disorders. J Autism Dev Disord. 2009;39(3): 405-413

20. Molloy CA, Manning-Courtney P. Prevalence of chronic gastrointestinal symptoms in children with autism and autistic spectrum disorders. Autism. 2003;7(2):165-171

21. Ming X, Brimacombe M, Chaaban J,ZimmermanBier B, Wagner GC. Autism spectrum disorders: concurrent clinical disorders. J Child Neurol. 2008;23(1):6-13

22. Valicenti-McDermott M, McVicar K, Rapin I, Wershil BK, Cohen H, Shinnar S. Frequency of gastrointestinal symptoms in children with autistic spectrum disorders and association with family history of autoimmune disease. J Dev Behav Pediatr. 2006;27(2 suppl):S128-S136

23. Parracho HMRT, Bingham MO, Gibson GR, McCartney AL. Differences between the gut microflora of children with autistic spectrum disorders and that of healthy children. J Med Microbiol. 2005;54 (pt 10):987-991

24. Lightdale JR, Siegel B, Heyman MB. Gastrointestinal symptoms in autistic children. Clin Perspect Gastroenterol. 2001;1:56-58

25. Afzal N, Murch S, Thirrupathy K, Berger L, Fagbemi A, Heuschkel R. Constipation with acquired megarectum in children with autism. Pediatrics. 2003;112(4):939-942

26. Wakefield AJ, Murch SH, Anthony A, et al Ileal-lymphoid-nodular hyperplasia, nonspecific colitis, and pervasive developmental disorder in children. Lancet. 1998; 351 (9103):637-641

27. Van den Brande P, Geboes K, Vantrappen G, et al. Intestinal nodular lymphoid hyperplasia in patients with common variable immunodeficiency: Iocal accumulation of $B$ and CD8(+) lymphocytes. J Clin Immunol. 1988;8(4):296-306

28. Iacono G, Ravelli A, Di Prima L, et al. Colonic lymphoid nodular hyperplasia in children: relationship to food hypersensitivity. Clin Gastroenterol Hepatol. 2007;5(3):361-366

29. Murch SH, Anthony A, Casson DH, et al. Retraction of an interpretation. Lancet. 2004; $363(9411): 750$

30. D’Eufemia P, Celli M, Finocchiaro R, et al. Abnormal intestinal permeability in children with autism. Acta Paediatr. 1996;85(9): 1076-1079

31. Christison GW, Ivany K. Elimination diets in autism spectrum disorders: any wheat amidst the chaff? J Dev Behav Pediatr. 2006; 27 (2 suppl):S162-S171

32. Committee on Educational Interventions for Children With Autism, Division of Behavioral and Social Sciences and Education, National Research Council. Educating Children With Autism. Lord C, McGee JP, eds. Washington, DC: National Academy Press; 2001

33. Carr EG, Horner RH, Turnbull AP, et al. Positive Behavior Support for People With Developmental Disabilities: A Research Synthesis. Washington, DC: American Association on Mental Retardation; 1999. American Association on Mental Retardation monograph series

34. Carr EG, Smith CE. Biological setting events for self-injury. Ment Retard Dev Disabil Res Rev. 1995;1(2):94-98 
35. Carr EG, Herbert MR. Integrating behavioral and biomedical approaches: a marriage made in heaven. Autism Advocate. 2008; $50(1): 46-52$

36. Carr EG, Smith CE, Giacin TA, Whelan BM, Pancari J. Menstrual discomfort as a biological setting event for severe problem behavior: assessment and intervention. Am J Ment Retard. 2003;108(2):117-133

37. Carr EG, Blakeley-Smith A. Classroom intervention for illness-related problem behavior in children with developmental disabilities. Behav Modif. 2006;30(6):901-924

38. Arnold GL, Hyman SL, Mooney RA, Kirby RS. Plasma amino acids profiles in children with autism: potential risk of nutritional deficiencies. J Autism Dev Disord. 2003;33(4): $449-454$

39. Dosman CF, Brian JA, Drmic IE, et al. Children with autism: effect of iron supplementation on sleep and ferritin. Pediatr Neurol. 2007;36(3):152-158

40. Hediger ML, England LJ, Molloy CA, Yu KF, Manning-Courtney P, Mills JL. Reduced bone cortical thickness in boys with autism or autism spectrum disorder. J Autism Dev Disord. 2008;38(5):848-856

41. American Dietetic Association. Food \& nutrition information: consumer resources. Available at: www.eatright.org/cps/rde/ xchg/ada/hs.xsl/nutrition.html. Accessed April 18, 2009

42. National Dairy Council. Nutrition \& product information. Available at: www. nationaldairycouncil.org/nationaldairycouncil/ nutrition. Accessed April 18, 2009

43. US Department of Agriculture. MyPyramid. gov: steps to a healthier you. Available at: www.mypyramid.gov. Accessed April 18, 2009

44. Curtin C, Bandini LG, Perrin EC, Tybor DJ, Must A. Prevalence of overweight in children and adolescents with attention deficit hyperactivity disorder and autism spectrum disorders: a chart review. BMC Pediatr. 2005;5:48

45. Hedley AA, Ogden CL, Johnson CL, Carroll MD, Curtin LR, Flegal KM. Prevalence of overweight and obesity among US children, adolescents, and adults, 1999-2002. JAMA. 2004;291 (23):2847-2850

46. Elder JH, Shankar M, Shuster J, Theriaque D, Burns S, Sherrill L. The gluten-free, casein-free diet in autism: results of a preliminary double blind clinical trial. J Autism Dev Disord. 2006;36(3):413-420

47. Weiland SK, von Mutius E, Hirsch T, et al. Prevalence of respiratory and atopic disorders among children in the east and west of Germany five years after unification. Eur Respir J. 1999;14(4):862-870
48. Matricardi PM, Rosmini F, Panetta V, Ferrigno L, Bonini S. Hay fever and asthma in relation to markers of infection in the United States. J Allergy Clin Immunol. 2002; 110(3):381-387

49. Scurlock AM, Lee LA, Burks AW. Food allergy in children. Immunol Allergy Clin North Am. 2005;25(2):369-388

50. Sampson HA. 9: food allergy. J Allergy Clin Immunol. 2003;111 (2 suppl):S540-S547

51. Anderson JA, Sogn DD, eds. Adverse Reactions to Foods. Washington, DC: US Government Printing House; 1984. AAAI-NIAID report, NIH publication $84-2442$

52. Bruijnzeel-Koomen C, Ortolani C, Aas K, et al. Adverse reactions to food. European Academy of Allergology and Clinical Immunology Subcommittee. Allergy. 1995;50 (8):623-635

53. Nowak-Wegrzyn A, Sampson HA. Adverse reactions to foods. Med Clin North Am. 2006; 90(1):97-127

54. Nowak-Wegrzyn A, Sampson HA, Wood RA, Sicherer SH. Food protein-induced enterocolitis syndrome caused by solid food proteins. Pediatrics. 2003;111(4 pt 1):829-835

55. Sicherer SH. Food protein-induced enterocolitis syndrome: case presentations and management lessons. J Allergy Clin Immunol. 2005;115(1):149-156

56. Farrell RJ, Kelly CP. Celiac sprue. N Engl J Med. 2002;346(3):180-188

57. McManus R, Kelleher D. Celiac disease: the villain unmasked? N Engl J Med. 2003; 348(25):2573-2574

58. Sampson HA. Food allergy, part 1: immunopathogenesis and clinical disorders. I A/lergy Clin Immunol. 1999;103(5 pt 1): 717-728

59. Ashwood P, Anthony A, Pellicer AA, Torrente F, Walker-Smith JA, Wakefield AJ. Intestinal lymphocyte populations in children with regressive autism: evidence for extensive mucosal immunopathology. J Clin Immunol. 2003;23(6):504-517

60. White JF. Intestinal pathophysiology in autism. Exp Biol Med (Maywood). 2003;228(6): 639-649

61. Torrente F, Anthony A, Heuschkel RB, Thomson MA, Ashwood P, Murch SH. Focalenhanced gastritis in regressive autism with features distinct from Crohn's and Helicobacter pylori gastritis. Am J Gastroenterol. 2004;99(4):598-605

62. Gupta S, Aggarwal S, Rashanravan B, Lee T. Th1- and Th2-like cytokines in $\mathrm{CD}^{+}$and $\mathrm{CD}^{+} \mathrm{T}$ cells in autism. J Neuroimmunol. 1998;85(1):106-109

63. Jyonouchi H, Sun S, Itokazu N. Innate immunity associated with inflammatory responses and cytokine production against common dietary proteins in patients with autism spectrum disorder. Neuropsychobiology. 2002;46(2):76-84

64. DeFelice ML, Ruchelli ED, Markowitz JE, et al. Intestinal cytokines in children with pervasive developmental disorders. Am J Gastroenterol. 2003;98(8):1777-1782

65. Jyonouchi H, Geng L, Ruby A, Reddy C, Zimmerman-Bier B. Evaluation of an association between gastrointestinal symptoms and cytokine production against common dietary proteins in children with autism spectrum disorders. J Pediatr. 2005;146(5): 605-610

66. Jyonouchi H, Geng L, Ruby A, ZimmermanBier B. Dysregulated innate immune responses in young children with autism spectrum disorders: their relationship to gastrointestinal symptoms and dietary intervention. Neuropsychobiology. 2005; 51(2):77-85

67. Ashwood P, Wakefield AJ. Immune activation of peripheral blood and mucosal $\mathrm{CD}^{+}$lymphocyte cytokine profiles in children with autism and gastrointestinal symptoms. J Neuroimmunol. 2006;173(1-2):126-134

68. Croonenberghs J, Bosmans E, Deboutte D, Kenis G, Maes M. Activation of the inflammatory response system in autism. Neuropsychobiology. 2002;45(1):1-6

69. Vargas DL, Nascimbene C, Krishnan C, Zimmerman AW, Pardo CA. Neuroglial activation and neuroinflammation in the brain of patients with autism. Ann Neurol. 2005;57(1): 67-81

70. Ashwood P, Wills S, Van de Water J. The immune response in autism: a new frontier for autism research. J Leukoc Biol. 2006;80(1): $1-15$

71. Croen LA, Grether JK, Yoshida CK, Odouli R, Van de Water J. Maternal autoimmune diseases, asthma and allergies, and childhood autism spectrum disorders: a case-control study. Arch Pediatr Adolesc Med. 2005; 159(2):151-157

72. Cabanlit M, Wills S, Goines P, Ashwood P, Van de Water J. Brain-specific autoantibodies in the plasma of subjects with autistic spectrum disorder. Ann N Y Acad Sci. 2007; 1107:92-103

73. Wills S, Cabanlit M, Bennett J, Ashwood P, Amaral D, Van de Water J. Autoantibodies in autism spectrum disorders (ASD). Ann N Y Acad Sci. 2007;1107:79-91

74. Wills S, Cabanlit M, Bennett J, Ashwood P, Amaral DG, Van de Water J. Detection of autoantibodies to neural cells of the cerebellum in the plasma of subjects with autism spectrum disorders. Brain Behav Immun. 2009;23(1):64-74 
75. Garty BZ, Ludomirsky A, Danon YL, Peter JB, Douglas SD. Placental transfer of immunoglobulin G subclasses. Clin Diagn Lab Immunol. 1994;1 (6):667-669

76. Braunschweig D, Ashwood P, Krakowiak P, et al. Autism: maternally derived antibodies specific for fetal brain proteins. Neurotoxicology. 2008;29(2):226-231

77. Croen LA, Braunschweig D, Haapanen L, et al. Maternal mid-pregnancy autoantibodies to fetal brain protein: the Early Markers for Autism study. Biol Psychiatry. 2008;64(7): 583-588
78. Martin LA, Ashwood P, Braunschweig D, Cabanlit M, Van de Water J, Amaral DG. Stereotypies and hyperactivity in rhesus monkeys exposed to IgG from mothers of children with autism. Brain Behav Immun. 2008; 22(6):806-816

79. Furlano Rl, Anthony A, Day R, et al. Colonic CD8 and gamma delta T-cell infiltration with epithelial damage in children with autism. J Pediatr. 2001;138(3):366-372

80. Torrente F, Ashwood P, Day R, et al. Small intestinal enteropathy with epithelial IgG and complement deposition in children with regressive autism. Mol Psychiatry. 2002;7 (4):375-382, 334

81. Schaefer GB, Mendelsohn NJ; Professional Practice and Guidelines Committee. Clinical genetics evaluation in identifying the etiology of autism spectrum disorders. Genet Med. 2008;10(4):301-305

82. Campbell DB, Buie TM, Winter H, et al. Distinct genetic risk based on association of MET in families with co-occurring autism and gastrointestinal conditions [published correction appears in Pediatrics. 2009;123(4):1255]. Pediatrics. 2009;123(3):1018-1024

\section{(Continued from first page)}

of Southern California, Los Angeles, California; 'WDivision of Child Development, Rehabilitation and Metabolic Diseases, Department of Pediatrics, University of

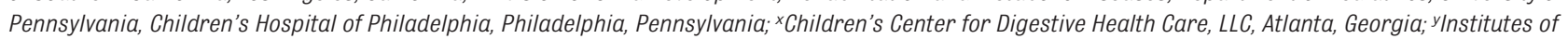
Pathology and Laboratory Medicine, Genomic Medicine, Neurology and Pediatrics, Cleveland Clinic, Cleveland, Ohio; 'Department of Pediatrics, Escola de Medicina, Universidade do Grande Rio, UNIGRANRIO, Brasilian Academy of Medicine, Rio de Janeiro, Brazil; aa Division of Gastroenterology, Hepatology and Nutrition, Children's Memorial Hospital, Northwestern University's Feinberg School of Medicine at Northwestern, Chicago, Illinois; ${ }^{b D}$ Department of Gastroenterology and Nutrition, Children's Hospital Boston at Peabody, Peabody, Massachusetts; ${ }^{c c}$ Pediatric Pain Program, Department of Pediatrics, David Geffen School of Medicine at University of California, Los Angeles, California

\section{KEY WORDS}

autism spectrum disorder, gastrointestinal, constipation, chronic diarrhea, abdominal discomfort, problem behavior, gluten-free casein-free diet

\section{ABBREVIATIONS}

ASD_autism spectrum disorder

PDD_-pervasive developmental disorder

NOS - not otherwise specified

GRADE - Grading of Recommendations Assessment, Development, and Evaluation

GERD - gastroesophageal reflux disease

FAP_-functional abdominal pain

IBS-irritable bowel syndrome

$\mathrm{NLH}$-nodular lymphoid hyperplasia

GFCF-gluten-free, casein-free

Ig-immunoglobulin

CNS - central nervous system

The guidance in this article is not intended to advocate for an exclusive course of treatment or to represent a standard of medical care. Individual circumstances will determine variations that may be appropriate.

www.pediatrics.org/cgi/doi/10.1542/peds.2009-1878C

doi:10.1542/peds.2009-1878C

Accepted for publication Sep 4, 2009

Address correspondence to Timothy Buie, MD, or Harland Winter, MD, Mass General Hospital for Children, Pediatric Gastrointestinal Unit, CRPZ 5-560, 175 Cambridge St, Boston, MA 02114.E-mail: tbuie@partners.org or hwinter@partners.org

PEDIATRICS (ISSN Numbers: Print, 0031-4005; Online, 1098-4275).

Copyright @ 2009 by the American Academy of Pediatrics

FINANCIAL DISCLOSURE: The Department of Molecular and Human Genetics at Baylor College of Medicine, of which Dr Beaudet is chair, derives revenue from genetic laboratory testing, including use of arrays for genomic copy-number analysis; Dr Winter has consulting agreements with AstraZeneca, P\&G, Salix Pharmaceuticals, Ltd, Takeda Pharmaceuticals North America, Inc, and UCB Inc Pharma and has received research grants from AstraZeneca, Centocor, Inc, P\&G, Nutricia North America Inc, SHS, Takeda Pharmaceuticals North America, Inc, UCB Inc Pharma and Wyeth Pharmaceuticals; and the Autism Forum provided honoraria to all authors. 


\section{Evaluation, Diagnosis, and Treatment of Gastrointestinal Disorders in Individuals With ASDs: A Consensus Report}

Timothy Buie, Daniel B. Campbell, George J. Fuchs, III, Glenn T. Furuta, Joseph Levy, Judy VandeWater, Agnes H. Whitaker, Dan Atkins, Margaret L. Bauman, Arthur L. Beaudet, Edward G. Carr, Michael D. Gershon, Susan L. Hyman, Pipop Jirapinyo, Harumi Jyonouchi, Koorosh Kooros, Rafail Kushak, Pat Levitt, Susan E. Levy, Jeffery D. Lewis, Katherine F. Murray, Marvin R. Natowicz, Aderbal Sabra, Barry K. Wershil, Sharon C. Weston, Lonnie Zeltzer and Harland Winter Pediatrics 2010;125;S1-S18 DOI: $10.1542 /$ peds.2009-1878C

$\begin{array}{ll}\text { Updated Information } & \text { including high-resolution figures, can be found at: } \\ \text { \& Services } & \text { http://www.pediatrics.org/cgi/content/full/125/Supplement_1/S } \\ \text { References } & \text { This article cites } 74 \text { articles, } 23 \text { of which you can access for free } \\ \text { at: } & \text { http://www.pediatrics.org/cgi/content/full/125/Supplement_1/S1 } \\ & \text { \#BIBL } \\ & \text { This article, along with others on similar topics, appears in the } \\ \text { following collection(s): } & \text { Gastrointestinal Tract } \\ \text { http://www.pediatrics.org/cgi/collection/gastrointestinal_tract } & \text { Information about reproducing this article in parts (figures, } \\ & \text { tables) or in its entirety can be found online at: } \\ \text { http://www.pediatrics.org/misc/Permissions.shtml } & \text { Information about ordering reprints can be found online: } \\ \text { http://www.pediatrics.org/misc/reprints.shtml }\end{array}$

